\title{
Types of fluid-related features controlled by sedimentary cycles and fault network in deepwater Nigeria
}

\author{
Marsset Tania ${ }^{1,{ }^{*}}$, Ruffine Livio ${ }^{1}$, Gay Aurelien ${ }^{2}$, Ker Stephan ${ }^{1}$, Cauquil E. ${ }^{3}$ \\ ${ }^{1}$ Ifremer (Institut Français de Recherche pour l'Exploitation de la Mer), UR GM, BP 70, 29280 Plouzané \\ Cedex, France \\ ${ }^{2}$ Géosciences Montpellier, Université Montpellier 2, UMR 5243 - CC 60, Place E. Bataillon, 34095 \\ Montpellier Cedex 5, France \\ ${ }^{3}$ TOTAL, Exploration \& Production, 24 Cours Michelet, 92069 Paris La Défense Cedex, France \\ * Corresponding author : Tania Marsset, email address : tania.marsset@lfremer.fr
}

\begin{abstract}
:
The seismic characteristics of focused fluid-related features such as pockmarks and carbonate buildups on the Nigerian continental slope have been investigated using complementary seismic data sets (reprocessed 3D exploration data and 2D Very High Resolution hull-mounted and near-bottom seismic data) coupled with the results of previous studies (sedimentological, geotechnical and geochemical analyses).
\end{abstract}

The results show different types of fluid-related features within the hemipelagic phase of long duration $(\sim 1 \mathrm{Myr})$ Turbidite/Hemipelagic cycles. They are the product of the disturbance of the hosting sediments following two main distinct processes: (1) no or low sediment deposition caused by fluid escape associated with seafloor settlement (benthic fauna, carbonate precipitation, gas hydrate formation) and (2) post-depositional erosion, caused either by fluid release (dewatering from underlying features such as channels and upward migration from a deep source) or by collapse (destabilisation of gas hydrates). The temporal evolution reveals a decrease in fluid flow during the hemipelagic deposition as witnessed by the decrease in methanogenic activity and by gas hydrate destabilisation. The spatial distribution of fluid-related features seems to be controlled by the type of fault (small fault or structural lineament).

\section{Highlights}

- Pockmarks classification was defined using seismic datasets at various scales. Use of geophysical signature of both fluid flow trails and hosting sediments. Depositional or erosional sedimentary disturbances lead to pockmarks formation. Implication of fluid flow and gas-hydrate dynamics on the sedimentary morphology. Control of faults and sedimentary cycles on spatiotemporal evolution. 
Keywords: Niger delta, Fluid flow, Pockmark, Gas hydrates, Methane-derived carbonate, Fault network, Sedimentary cycles 


\section{Introduction}

Since the 70 s, fluid-related features such as pockmarks and carbonate mounds have been discovered and increasingly explored through multidisciplinary approaches in a variety of oceanographic and tectonic contexts. These surface and sub-surface features are commonly linked to fluid flow as their inception, evolution and morphology are deeply influenced by the mode, type and intensity of fluid expulsion (Arntsen et al., 2007; Bailey et al., 2003; Bayon et al., 2007; Dumke et al., 2014; Gay et al., 2006; Gay et al., 2007; Hjelstuen et al., 2010; Judd and Hovland, 2009; Karisiddaiah and Veerayya, 2002; Rollet et al., 2006; Suess, 2014). The availability of numerous well-documented examples have allowed to classify fluid-related features based on different criteria such as shape, size, ground composition, spatial distribution and relationships with geology, fluid flux and the nature of the seabed (Gay et al., 2007; Greinert et al., 2001; Judd and Hovland, 2009; León et al., 2006; Pilcher and Argent, 2007).

Several recent publications have focussed on the processes preceding the formation of fluid-related features and their subsequent evolution through time (Gay et al. 2012; Ho et al., 2012; Leduc et al., 2013; Pau et al., 2014; Riboulot et al, 2016; Sultan et al., 2010). On a geological time scale, the recurrence of fluid-related features has been observed at different stratigraphic levels and relationships have been established with global controlling factors such as climate-driven sea level variations (e.g. Gay et al., 2007; Riboulot, 2011). 
These studies emphasized the importance of a detailed qualitative analysis of the vertical evolution of fluid-related features. However, the precise interaction between fluid flow, sedimentary processes (syn and post depositional) and fault activity is still poorly documented. With the aim to obtain further insights into the links between these processes, this paper is focused on the detailed analysis of fluid-related features (pockmarks and carbonate build-ups) and their relationships with the tectono-sedimentary environment in deepwater Nigeria.

Reprocessed 3D exploration and 2D Very High Resolution (VHR) such as hull-mounted and deep-towed seismic sources have provided high-resolution data to support the seismic analysis. Attention was paid to both the geometry of the fluid-related features and their associated seismic anomalies by integrating their evolution over time. This analysis has been calibrated with the information provided by previous studies from cores (sedimentological, geotechnical and geochemistry analyses) in order to improve discussions on the interplay between fluid flow, sedimentary processes and fault activity.

\section{Geological background and previous work}

The study area is located in the Gulf of Guinea, south of Nigeria and seaward of the modern Niger Delta (Fig. 1). The Niger delta is a sedimentary wedge of $12 \mathrm{~km}$ thick which has prograded over $300 \mathrm{~km}$ since the late Eocene over a marine shale-rich formation in response to the evolving drainage area, basement subsidence and sea-level changes (Burke, 1972; Doust and Omatsola, 1990; Evamy et al., 1978; Short and Stauble, 1967; Stacher, 1995; Whiteman, 1982). During the Plio-Pleistocene, the stacking patterns of sedimentary sequences were mainly controlled by climate-driven sea level changes (Jermannaud et al., 2010). The sedimentary accumulation was influenced by gravity-driven tectonics rooted to regional detachments associated with over-pressured shales (Corredor et al., 2005; Damuth, 1994; Hooper et al., 2002 among others). This regional deformation 
formed a shallow-water extensional domain of growth faults (Doust and Omatsola, 1990; Evamy et al., 1978; Knox and Omatsola, 1988; Weber and Daukoru, 1975) compensated by a deep water compressional domain of fold and thrust belt and an intermediate zone slightly affected by deformation (Damuth, 1994; Corredor et al., 2005; Morley and Guerin, 1996; Wu and Bally, 2000). Numerous studies on the Nigerian continental slope have documented the occurrence of a wide range of seafloor sedimentary features such as pockmarks, chimneys, mud volcanoes and carbonate build-ups. They have been associated either with fluid flow and/or gas hydrates and commonly occur on structural features such as folds and major faults (Brooks et al., 2000; Cunningham and Lindholm, 2000; Graue, 2000; Haskell et al., 1999; Heggland et al., 2001, Heggland, 2003; Kopf, 2002; Leduc et al., 2013; Loseth et al., 2010; Riboulot et al., 2011, 2013; Ruffine et al., 2013; Sultan et al, 2007, 2010, 2011, 2014; Yahaha, 2000) as well as on sedimentary features such as channels (Davies, 2003). Some of these fluid-related features are related to small-scale deformation caused by overpressure and sediment remobilisation, for instance fluid flow pipes and mud volcanoes (Graue, 2000; Heggland et al., 2001; Kopf, 2002; Leduc 2013) and fluidization features (Davies, 2003).

This work is a continuity of several multidisciplinary studies on the study area (projects Neris 2002-2006 and ERIG 3D 2008, joint collaborations between Total and Ifremer) which provided a first description of the local tectono-sedimentary setting and numerous results on the processes related to the gas hydrate dynamics and carbonate precipitation (Bayon et al., 2007; George and Cauquil, 2007; Riboulot et al., 2011; Rongemaille et al., 2011; Ruffine et al., 2013; Sultan et al, 2007, 2010, 2011, 2014). The contribution of this present work is to highlight the implication of time varying fluid flow and gas hydrate dynamics and subsequent seafloor settlement (carbonate precipitation, fauna activity, gas hydrate stability) on the sedimentary disturbances (depositional or erosional) leading to the genesis of pockmarks. This contribution is also to highlight the role of the fault network on fluid flow intensity and/or continuity and the influence of the sedimentary pattern on pockmark re-occurrence.

\section{Data and methods}


The results presented in this paper are derived from the interpretation of several geophysical data sets including:

(1) Bathymetric and sub-bottom Profiler data acquired using an Autonomous Underwater Vehicle (AUV) (George and Cauquil, 2007) which provided a detailed map of the seafloor from a dense grid of profiles. In addition, the dataset includes a map of the variations of echo facies. The AUV system operated at an average altitude of $40 \mathrm{~m}$ above the seafloor. The source produces frequency modulated or "chirped" pulses in the $2-16 \mathrm{kHz}$ bandwidth. The vertical resolution is in the order of $10 \mathrm{~cm}$.

(2) 3D reprocessed seismic data made available by Total SA. The primary source of data is conventional exploration $3 \mathrm{D}$ seismic reflection data. The data were collected using dual air-gun sources (frequency bandwidth of $150 \mathrm{~Hz}$ ) and four multi-channels streamers (trace spacing of $15 \mathrm{~m}$ ) with an acquisition array of $25 \times 25 \mathrm{~m}$. For an optimal study of shallow hazards in deepwater, a 3D short offset reprocessing was carried out using patented industrial processing software from Total. The reprocessed 3D block consists of a cube of elementary cells (12.5 x $12.5 \mathrm{~m}$ in $\mathrm{X} \times \mathrm{Y}$ and $5 \mathrm{~m}$ in $\mathrm{Z}$ i.e. depth).

(3) A single 2D Very High Resolution (VHR) hull mounted Sub-Bottom Profiler (SBP) seismic record acquired by Ifremer during the Neris survey with a frequency bandwidth of $1.8-5.2 \mathrm{kHz}$.

(4) Near-bottom SYSIF (SYstème Slsmique Fond) seismic data acquired by Ifremer during the Neris and ERIG3D surveys. SYSIF is a deep-towed seismic apparatus hosting one of two different low-frequency acoustic transducers and a single channel streamer in order to provide High Resolution (transducer JH220-6000: HR 220-1050 Hz) or Very High Resolution (transducer JH650-6000: VHR 650-2200 Hz) seismic sections of the upper sedimentary layers (Ker et al., 2010; Marsset et al., 2010). SYSIF acquisition at an altitude of 50-100 m above the seafloor offers a vertical resolution of $0.5 / 1 \mathrm{~m}$ and horizontal resolution of $6 / 15 \mathrm{~m}$ in water depths down to $6000 \mathrm{~m}$. 
The seismic interpretation is based on: (1) the analysis of the reflectors' lateral terminations (onlap, downlap, erosional truncation) according to the general principles of seismic stratigraphy (Mitchum et al., 1977); and (2) characterisation of seismic facies and correlation of distinctive reflectors between profiles. 3D seismic was used to define the seismic units whereas SYSIF was used to define the sub-units within units with a higher resolution.

The cross-correlation between the complementary datasets leads to a classification of the depressions depending on: their morphologies at seafloor (using AUV bathymetry), their detailed structures within the hosting sediments (using SYSIF and SBP data), their stratigraphic location (using SYSIF data), their recurrence within the sediments (using SYSIF and $3 \mathrm{D}$ seismic data) and their spatial distribution versus the location of faults and buried channels (using 3D seismic data). The classification of depressions relies on the pair correlation between the type of sedimentary depression and the type of High-Amplitude seismic Anomalies (HAA). The HAA anomalies have been classified (using SYSIF seismic facies) and mapped (using AUV echo-facies and their correlation with SYSIF and 3D facies) in order to obtain their exhaustive spatial distribution and extent. The type of depression is defined from different morpho-stratigraphic variables such as depression shape (e.g. Vshape, irregular-shape), pattern of hosting sediments and sidewall characteristics (e.g. bending or truncation of reflectors), internal structure (empty, filled). The type of HAA in the depression bottom is defined by its shape (e.g. flat-shaped) (Fig. 2).

\section{Results}

\subsection{Structural framework}

The study area covers a surface of around $6 \times 5 \mathrm{~km}^{2}$ and lies in water depths ranging from 1100 to $1250 \mathrm{~m}$ (Fig. 3A). The area corresponds to the top of a structural antiform generated 
by folding. The collapsed summit of the anticline is bound by two main deep-rooted normal faults. These two structural north and south lineaments (NL and SL) are oriented N130 (Fig. 3B) and delineate a crestal graben where faults are commonly observed (Sultan et al., 2007, $2010,2014)$. In this study, two families of structures marked by vertical offsets of reflectors (Fig. 4A) were distinguished in the area. The first one encompasses both deep and shallow structures surrounding the graben (Fig. 4C). The second one consists of a grid pattern of very small SW-NE and NW-SE oriented structures in the graben (Fig. 4B, Zoom).

\subsection{Definition and characteristics of seismic units}

From bottom to top, the sedimentary record in 3D lines consists of a recurrent motif of two (lower and upper) units (Fig. 5). The lower unit, labelled UT (interpreted as Turbidite deposits, see section 5.1), is characterised by poorly developed channel/levee systems that laterally evolve to low-amplitude continuous reflectors. The youngest UT encompasses the recent channels visible on the seafloor (Fig. 3A) while the older ones show buried channels characterised by sinuous pathways on time slices (Fig. 4C). The upper unit, labelled UH (interpreted as Hemipelagic deposits, see section 5.1), shows continuous internal reflections and low-to-moderate acoustic amplitudes. The base of the youngest UH is marked by a reflector $R$ showing flat-shaped High Amplitude Anomalies (HAA) laterally connected to very high amplitude cone-shaped seismic anomalies i.e. bright spots. Numerous stacked offsets of reflectors and stacked seismic anomalies are also observed on the seismic section (Fig. $5)$.

On SYSIF profiles, the low seismic penetration allowed only to image the youngest UT and $\mathrm{UH}$ units. From bottom to top, UH splits into seven distinct sub-units $\mathrm{UH} 7$ to $\mathrm{UH} 1$ (Fig. 6). These sub-units, except UH7, are bound at their top by a discontinuity related to depressions (Fig. 6 and Fig. 7). UH7 is characterised by low-to-moderate amplitude chaotic seismic facies and tends to smooth the topography inherited from channels (Fig. 6 and Fig. 
7). UH6 to UH4 show low amplitude parallel undulated reflectors which pass locally to seismic anomalies (patch or dome-shaped) where depressions occur (Fig. 6 and Fig. 7). These sub-units are increasingly thick and the depressions are increasingly deep from UH6 to UH4 (Fig. 7). UH6 and UH5 tops are marked by very high-amplitude continuous reflectors (Fig. 6) which merge into the $\mathrm{R}$ reflector on $3 \mathrm{D}$ lines (Fig. 5). UH3 to UH1 are increasingly thick and stratified sub-units with low-amplitude reflectors. The top of $\mathrm{UH} 2$ is characterised by very high-amplitude parallel continuous reflectors. The upper part of $\mathrm{UH} 3$ to $\mathrm{UH} 1$ is locally bound by various types of depressions usually characterised by seismic anomalies in their centres (Fig. 6 and Fig. 7). It is worth noting that cone-shaped very high-amplitude seismic anomalies are locally identified where they relate to the bright spots identified in the $3 \mathrm{D}$ seismic data. The base of the cone occurs in UH6 and its top can reach UH1 (Fig. 6).

\subsection{Morphology and distribution of depressions}

Numerous circular to sub-circular depressions, with diameters and depths ranging from a few meters to 700 meters and a few meters to 110 meters respectively, occur over both the two structural lineaments that delineate the graben and within the graben (Fig. 3A) (George and Cauquil, 2007; Sultan et al., 2007).

\subsubsection{Types of depressions and associated seismic anomalies}

\subsubsection{1) Non depositional depression (NDD)}

About 30 depressions of NDD type have been identified in the study area (Fig. 8B). The sidewalls of the most simple NDD called the Single NDD-HAAF (one depression affecting one sub-unit) are defined by the downward bending of the reflectors of the hosting sub-unit (Fig. 2A; Fig. 8A). The sub-unit becomes very thin and terminates within the depression thus generally leading to a depositional hiatus in the centre. This change in the stratal pattern 
results in a discontinuity. The bottom of the depression is frequently associated with flatshaped High-Amplitude Anomalies (HAAF) (Fig. 8A case 1). These depressions are 100-800 $\mathrm{m}$ wide but only reach $10 \mathrm{~m}$ depth. They are buried and therefore not marked on the bathymetry (Fig. 8B case 1). The Single NDD-HAAF are often stacked vertically from UH6 to UH4 with a stacking pattern of anomalies forming the NDD-HAAF(Fig. 2A; Fig. 8A case 2).

NDD stacked from UH6 to UH4 also may be associated with dome-shaped High Amplitude Anomalies (HAAD), about $15 \mathrm{~m}$ high, and present an acoustic mask underneath (i.e. NDD-HAAD on Fig. 2A; Fig. 8A case 3). A few SYSIF sections crossing these buried features along two orthogonal directions reveal a sub-circular shape (Fig. 8B case 3). Most of the NDD-HAAF and NDD-HAAD appear within the graben (Fig. 8B). Several of them occur above stacked offsets of reflectors (Fig. 6, Fig. 7).

On 3D seismic sections, cone-shaped High-Amplitude Anomalies (HAAC) can be associated with NDD-type depressions (i.e. NDD-HAAC on Fig. 2A and Fig. 5). In these cases, the Top of NDD-HAAC appears as a wide depression $1 \mathrm{~km}$ long and up to $50 \mathrm{~m}$ deep, in relation to significant thinning of the UH unit. The NDD-HAAC are generally observed above offsets of reflectors and the HAAC locally creates a bright spot (Fig. 5). On SYSIF, the HAAC consist of chaotic facies enhanced by very high-amplitude parabolic reflections and diffraction hyperbolae which result from the amalgamation of seismic anomalies. These seismic anomalies cannot be differentiated for each of the stacked NDD from UH6 to UH1 (Fig. 8A case 4 and case 5 i.e. pockmark C2). On the AUV bathymetry, the tops of NDDHAAC appear on the seafloor as depressions with rough morphology (Fig. 8B). They show irregular shapes within the graben (Fig. 8B case 4 and case 5) and an elongated shape along a NW-SE oriented axis in the NE area (Fig. 8B case 6 and case 7, Fig. 9 case 6).

\subsubsection{2) Erosional Depressions (ED)}


These depressions are defined by an erosional unconformity due to the truncation of the reflections of the hosting sub-unit (Fig. 2B; Fig. 10A case 8). The sediment of the sub-unit can be partially or completely eroded.

ED can be buried and occur at UH3 and UH2 tops as $800 \mathrm{~m}$ wide and $15 \mathrm{~m}$ deep craters (Fig. 10B). They are often associated with High-Amplitude Anomalies (HAAF on Fig. 10A case 8, HAAD on Fig. 10A case 9). The ED-HAAF are onlapped by sediments. The ED observed at the Top of $\mathrm{UH} 1$, i.e. the seabed, can be characterised by very irregular shapes ranging from shallow to deep depressions: 1) On the AUV map, the shallow depressions are ring-shaped with a set of intersecting rims and rough morphology in the centre (Fig. 10B case 10 i.e. pockmark A). Patch-shaped HAA (HAAP) appear beneath the depression. The ring-shaped ED-HAAP are not well expressed on 3D seismic data; however, numerous offsets of reflectors are observed underneath these structures (Fig. 5, pockmark C1). On the SYSIF profile these depressions present a pattern of high amplitude anomalies and the hosting sediments are only partially eroded (Fig. 6 pockmark C1, Fig. 7 pockmark A and Fig. $10 \mathrm{~A}$ case 10$) ; 2$ ) the deep depressions are craters, up to $45 \mathrm{~m}$ deep and 500 by $1000 \mathrm{~m}$ wide, which cut shallow sub-surface reflectors. A set of chaotic deposits is observed at the bottom of the crater (Fig. 11 case 11 ).

Another category of ED, the V-shaped depression, has been identified in the area. The biggest one, $700 \mathrm{~m}$ wide and $110 \mathrm{~m}$ deep, is clearly visible in both 3D seismic lines (Fig. 4A) and SYSIF profiles (Fig. 12A case 12 i.e. pockmark giant). The sidewalls of the depression display a V-shaped structure and are defined by the truncation of hosting reflectors. However, in contrast to the irregular-shaped ED, the V-shaped depression is regular in shape and connected to a deep-rooted transparent anomaly (Fig. 4A).

Some smaller $100 \mathrm{~m}$ wide ED are aligned SW-NE (Fig. 13 case 13). Another type of NWSE ED train occurs in the western part of the area (Fig. 13A case 14).

\subsubsection{3) Topographic lows related to underlying paleo-depressions}




\section{ACCEPTED MANUSCRIPT}

It is worth noting that 200 to $500 \mathrm{~m}$ wide depressions are observed on the seafloor and are defined by basal conformity (Fig. 14A). They are due to the presence of a marked underlying paleo-depression (buried NDD or ED), draped with sediment i.e. showing an internal seismic configuration parallel to the underlying topography (Fig. 14B case 15 and case 16 , Fig. 15 case 17 i.e. pockmark C3). Enhanced reflections may occur within the draping above the buried depression (Fig. 15 case 17 i.e. pockmark C3). As these depressions are residual topographic lows related to underlying paleo-depressions, they have not been classified.

\subsubsection{Vertical sequence of different types of depressions}

Two complex sequences of different types of vertically stacked depressions can be distinguished. The first example (Fig. 11A case 11 i.e. pockmark peanut) consists of a NDDHAAD from UH6 to UH4, followed upward by two ED at the UH3 and UH2 tops which are then partially filled and finally draped by sediment. This sequence terminates with a deep ED at $\mathrm{UH} 1$ top which overcuts the sediment from UH1 to UH3 over a depth of $40 \mathrm{~m}$. The slight lateral shifts between the stacked depressions give a final complex shape on the seafloor called the peanut shape. The sequence shows a morphological link between the depressions. The second example (Fig. 15 case 17) displays the same NDD-HAAD from UH6 to UH4, overlain by two ED (at $\mathrm{UH} 3$ and $\mathrm{UH} 2$ tops). It terminates with the draping of sediment. A topographic low reflecting the sequence of underlying depressions is observed on the seafloor.

\subsubsection{Spatio-temporal distribution of depressions}

Firstly, the results show the arrangement of depressions within the youngest $\mathrm{UH}$ with respect to the tectonic structures, northern and southern structural lineaments and the major 
eastern fault (preferentially NDD-HAAC) but also with respect to the graben (all NDD and all ED) (Fig. 16). Moreover, the results evidence the spatio-temporal link between them, in particular the vertical sequences of several types of depressions (e.g. peanut, B, C1, C2 and C3 among others) within the graben. It is worth noting that a possible confusion may be made between the topographic lows related to a paleo-depression and the ring-shaped ED that may present similar characteristics on the AUV seafloor map but different internal structures on seismic profiles.

Secondly, the thickness map between R (see Fig. 5 for location), identified in 3D seismic data, and the seafloor allowed to complete the identification of NDD-HAAC as they correspond to the lowest values of thickness (in blue on Fig. 17C). The differences between NDD-HAAC (e.g. pockmark C2) and other deep depressions such as deep irregular-shaped ED (e.g. pockmark peanut) or V-shaped ED (e.g. pockmark giant) is made by checking the presence of bright spots on small sections from the $3 \mathrm{D}$ lines. Zones corresponding to the seafloor topographic trough related to underlying draped paleo-depressions (e.g. pockmark B) have been distinguished (from light brown to green, depending on the burying depth of the paleo-depression on Fig. 17C).

Thirdly, the comparison between the echo facies from AUV sub-bottom profiler data, with the seismic facies on SYSIF and 3D lines shows that the echo facies map can be used to emphasize the distribution of the different types of HAA. The HAAF and HAAD represent zones of wide extent covering the eastern part of the study area. Most of the HAAC are buried except for some spots which outcrop on the seafloor. Very few HAAP occur with a small extent. These HAA pass laterally to the $\mathrm{R}$ reflector which covers the rest of the zone (Fig. 18)

\section{Interpretation and discussion}

\subsection{Hosting sediments: a record of variable duration sedimentary cycles}


Sediments at the seabed of the study area are composed of hemipelagic deposits (Bayon et al., 2007, Sultan et al., 2007). These sedimentary facies appear on seismic sections as high-continuity, low-amplitude stratified reflections.

The seismic characteristics of UT/UH suggest the occurrence of alternating turbidite/hemipelagic sedimentary units (Fig. 5). Indeed, within the youngest UT/UH, the turbidite phase encompasses a few channels within interpreted turbidite deposits. The hemipelagic phase shows the transition from a basal filling sub-unit (low amplitude chaotic facies interpreted as turbidite deposits) which marks the abandonment of channels (UH7), to increasingly draping sub-units (low amplitude stratified reflectors attributed to hemipelagic sediments) from UH6 to UH1 (Fig. 6).

The mean sedimentation rate of the hemipelagic sediments of the area has been estimated at around $8 \mathrm{~cm} / 1000 \mathrm{yr}$ based on previous work (Fig. 17A) (10.6 m long N1-KSF39 core; Bayon et al., 2015). This value is in agreement with regional sedimentation rate values of 1) Pastouret et al. (1980) i.e. $7.2 \mathrm{~cm} / 1000 \mathrm{yr}$ based on a $15 \mathrm{~m}$ long core of hemipelagic sediments, located $140 \mathrm{~km}$ northwestwards at about $1300 \mathrm{~m}$ water depth and covering the last $180 \mathrm{kyr}$ and 2) Zabel et al. (2001) i.e. $8.3 \mathrm{~cm} / 1000 \mathrm{yr}$ based on a $20 \mathrm{~m}$ long core of clay located $30 \mathrm{~km}$ southwards at $2200 \mathrm{~m}$ water-depth and covering the last $245 \mathrm{kyr}$. The total thickness of UT/UH (up to $\sim 100 \mathrm{~m}$ ), outside the channels where UT correspond to hemipelagic sediments, together with the estimated mean sedimentation rate, gives a duration of around $1 \mathrm{Myr}$ for UT/UH. This duration approximately equals sequence stratigraphic third-order cycles (Haq et al., 1988; Hardenbold et al., 1998). As internal subunits $\mathrm{UH} 6$ to $\mathrm{UH} 1$ are 8-12 m thick, we interpreted them as related to fourth-order (100 kyr) glacio-eustatic cycles. Long-duration (around $1 \mathrm{Myr}$ ) and short-duration (around 0.1-0.4 Myr) sedimentary cycles attributed to climate-driven eustasy have been identified within deepwater sediments of the Niger delta by other studies (Damuth, 1994; Riboulot et al., 2011 and Jermannaud et al., 2012). 


\subsection{Pockmarks: a product of fluid dynamic in hosting sediments}

The morphological signature of depressions and their associated seismic anomalies correlated to sedimentology, major element geochemistry, pore water chemistry, petrography, mineralogy (Bayon et al., 2007), and in-situ geotechnical measurements such as piezocone penetration (Sultan et al., 2007) allowed us to define these features as the product of fluid escape.

\subsubsection{Pockmarks with carbonate build-ups}

During previous coring (e.g., core N1-KS22 in Fig. 17A) within NDD-HAAC aggregates of cemented shells were recovered in the bottom of the depression (Bayon et al., 2007). These aggregates were interpreted as dead chemoherm carbonates (based on Greinert et al., 2001) indicative of strong past fluid activity (Bayon et al., 2007). Upward fluid migration favours the development of chemosynthetic communities on the seafloor and precipitation of authigenic carbonates such as aragonite which cements the sediment (Bayon et al., 2007). The seismic characteristics of the NDD-HAAC, such as high reflectivity facies, acoustic masking and bright spots, are consistent with the occurrence of consolidated sediments such as carbonate build-ups. The shifts of seismic anomalies from one sub-unit to another suggest that their growth over time is partly controlled by lateral shifts of fluid flows and therefore polyphased (Fig. 8A case 4 and case 5). These carbonate build-ups appear as perdurable structures from UH6 to UH1. However, most of them are abandoned features presently sealed by the hemipelagic drape.

No direct geochemical information is available in NDD-HAAF and -HAAD to determine their nature. However, the geometric dimension and the high-reflectivity bottom facies of single NDD-HAAF are similar to the characteristics of the giant Regab pockmark observed at the Lower Congo Basin. The active zone of the Regab pockmark shows thick carbonate 
mounds (authigenic materials) which can host abundant living fauna in areas with intense gas emissions and gas hydrate occurrence (Gay et al., 2006; Marcon et al., 2014; Ondreas et al, 2005; unpublished SBP data acquired during the WACS survey on Fig. 8). Therefore, we advocate a similar fluid-related origin for HAAF and HAAD. NDD-HAAF and -HAAD are interpreted as stacked pockmarks with authigenic carbonates and chemosynthetic communities formed near the seafloor environment, resulting from methane-saturated fluid expulsions (Bayon et al., 2007; Kastner et al., 2008; Niewöhner et al., 1998; Reeburgh, 1976; Snyder et al., 2007).

However, as HAAF are less developed than HAAC, the fluid escape is supposed to be less intense and/or less continuous. HAAF may consist of fossil evidence (mineralogical, chemical and/or biological) of small seafloor facies produced by upward fluid migration along faults. The vertical alignment of the Single NDD-HAAF from UH6 to UH4 forming the NDDHAAF suggests genetically related pockmarks recording the variation of fluid flow intensity and continuity (Fig. 8A case 2). For the case of NDD-HAAD, their formation could also be caused by the local upward deformation created by the overpressured fluid beneath of a poorly permeable layer. This deformation is followed by a consolidation of the dome by carbonated cementation (Mazzini et al., 2008). This kind of structure can be filled with gas hydrates if formed within the Gas Hydrate Stability Zone and may be analogue to hydrate domes covered by hemipelagites (Fisher, 1997). Since both NDD-HAAF and -HAAD appear only in the interval covering $\mathrm{UH} 6$ to $\mathrm{UH} 4$, they are considered ephemeral structures.

\subsubsection{Pockmarks resulting from fluid release}

Conical V-shaped depressions are usually interpreted as recent or active pockmarks (Pilcher and Argent, 2007). The crater-like nature of these pockmarks suggests an erosional action of fluid release, commonly related to an overpressured buried reservoir of gas, oil or interstitial water, or a combination of the three (Hovland and Judd, 1988). According to Gay et al. $(2012,2017)$, the fluid pipe induces a deformation of surrounding unconsolidated 
sediments during upward migration leading to the formation of a V-shaped structure (Gay et al., 2012; 2017). Previous geochemical analyses revealed a very low methane content within the giant V-shaped ED occurring in the study area (Fig. 12). In addition, carbonates are not identified on the seabed (Bayon et al., 2007). This is consistent with low amplitudes at the bottom of this structure possibly indicating a past or remnant activity of fluid venting. Therefore, the giant V-shaped ED is interpreted as an abandoned giant pockmark. The observed geometry can be explained by a strong fluid release from depth as suggested by the presence of an underlying acoustic pipe (see Fig. 4A) followed by a collapse of the structure.

The sinuous organization of ED pockmarks (case 13 on Fig. 13) is similar to pockmark belts indicating an upward fluid escape from a shallow buried channel (Gay et al., 2006; Haskell et al., 1999). Migration pathways may have originated along a weak interface that formed at the channel margins due to differential compaction over time and dewatering (Gay et al., 2003).

The ED pockmark train over the southern structural lineament has not been investigated by seismic data; however, it may correspond to fault-strike pockmarks as described by Hovland and Judd (1988) or by Gay et al. (2006). Such faults may create pathways for fluid migration (Boe et al., 1998; Dimitrov and Woodside, 2003; Eichhubl et al., 2000; Soter, 1999; Vogt et al., 1999).

\subsubsection{Pockmarks with massive gas hydrates}

Sultan et al. (2010) suggested that the ring-shaped depressions are the result of gas hydrate dissolution. A local decrease in the gas flow at the base of the Gas Hydrate Stability Zone combined with seawater inflow could explain the gas hydrate dissolution (gas hydrates being dissolved in seawater) and the creation of a crater. The distribution of the very highamplitude facies in their centres is attributed to the saturation by gas hydrates of vertical and 
lateral fractures created by the migration of gas (Sultan et al., 2014). Massive gas hydrates have been retrieved by coring from ring-shaped ED-HAAP, e.g. Pockmark A displayed in Figure 8 of Sultan et al. (2010). The depressions are associated with authigenic carbonates (Bayon et al., 2007) which could explain the occurrence of seismic amplitude anomalies on the seafloor. The authigenic carbonates are often aragonite concretions, indicative of methane release into the water column leading to high methane concentration near the sediment seawater interface. At this interface, part of the methane is oxidized into carbonate ions, and this relation triggers authigenic phase precipitations (Bayon et al., 2007).

Sultan et al. (2010) proposed an evolutionary sequence for pockmarks related to the dissolution of gas hydrates from a morphologically immature pockmark to a mature pockmark (respectively pockmarks A and B on Fig. 3). Note that, from this revised and detailed analysis of pockmarks, we propose peanut as an example of a mature pockmark (Fig. 11 case 11). Peanut shows an irregular morphology and the presence of collapsed sediments at the bottom whereas pockmark $B$ is a topographic low related to a paleo-depression (Fig. 14). The few enhanced reflections observed within the draping sediments of pockmark B suggest fluid migrates through the sedimentary cover from the fossil depression. The vertical stacking pattern of depressions beneath peanut suggests a link between them as observed for $\mathrm{C} 3$ (Fig. 15). The pockmarks with gas hydrates appear over faults (e.g. Fig. 5 pockmark C1). From these results, we interpret all ring-shaped ED-HAAP of the study area as immature gas hydrate-bearing pockmarks (e.g. pockmark A Fig. 10A case 10).

The buried deep irregular-shaped ED are the most enigmatic features, as they have not been sampled yet. However, taking into account the widespread gas hydrate occurrences in the area and their stratigraphic location at the top of UH3, rich in NDD-HAAF and NDDHAAD), these features can be regarded as craters with relic carbonate crusts (HAAF) and domes (HAAD). This may be due to sediment removal of an initial NDD after gas hydrate dissociation related to a drastic change in temperature, pressure and/or salinity conditions caused by a sea level fall for instance (MacDonald, 1990). This could also be due to collapse of sediments after the dissolution of gas hydrates, caused by a volume loss. In both cases 


\section{ACCEPTED MANUSCRIPT}

the missing or removed material left a HAAD relic as carbonates are probably too hard to evacuate from the ED.

\subsection{Temporal evolution}

Two main chronological stages appear in fluid activity within the youngest UH. The first stage is viewed as dominated by gas hydrate formation, chemosynthetic fauna accumulations and the production of methane-derived authigenic carbonates that corresponds to the genesis of pockmarks with carbonates forming the NDD-HAAF, -HAAD, and -HAAC. The process involved in pockmark formation is differential sedimentation. When fluids are expelled on the seafloor, they form a plume spreading out and preventing sediment deposition (Chand et al., 2009; Gay, 2002; León et al., 2010; Moss et al., 2012; Ostanin et al., 2013). The sediment winnowing would explain both the thinning of the hosting sedimentary layers around the interpreted carbonate build-ups or crusts of NDD-HAAC, HAAD and -HAAF and the sediment hiatus in the centre of depressions (Fig. 5, Fig. 6, Fig. 7,

Fig. 8 case 1). Both, i) the high density of NDD-HAAF and -HAAD between UH6 and UH4 and their absence from $\mathrm{UH} 3$ to $\mathrm{UH} 1$ and ii) the scarcity of NDD-HAAC from $\mathrm{UH} 6$ to $\mathrm{UH} 1$ and their present sealing by hemipelagic deposits, suggest that sediment winnowing would have prevailed in the pockmark formation between units $\mathrm{UH} 6$ and $\mathrm{UH} 4$ and is no longer active.

The second stage in fluid activity is viewed as dominated by post-depositional sediment reworking with a weak chemosynthetic fauna activity. It can be caused by the erosion of surrounding sediments due to fluid release, as it is suggested for isolated conical depressions (Hovland et al., 1984, 2005) or for pockmark trains associated with underlying organized structures (Eichhulb et al., 2000; Forwick et al., 2009; Pilcher and Argent, 2007; Gay et al., 2003; Casenave et al., 2017). This may be the case for the V-shaped ED i.e. our giant pockmark (intense and short fluid release from a deep source) and for ED trains over channels (fluid release due to overpressurized pore-fluids) or over faults (fluid migration 
along fault planes). This may also be due to the collapse of sediments following the dissolution of gas hydrates in underlying sedimentary layers and caused by a local decrease in gas flow at the base of the Gas Hydrate Stability Zone (Bayon et al., 2015; Davy et al., 2010; Riboulot, 2016; Sultan et al., 2010, 2014). The presence of erosional structures from UH3 (deep irregular-shaped ED-HAAF and HAAD) to the seafloor (ring-shaped ED-HAAP, Vshaped ED, ED trains), suggests that post-depositional sediment reworking has prevailed since UH3. The decreasing trend in fluid activity from stage 1 to stage 2 is coherent with the decrease in the density of pockmarks from UH6 to UH1. Two processes can explain this change in fluid activity: the sealing of carbonate mounds, i.e. self sealing in the sense of Hovland (2002) and/or a halt in the fluid supply related to fault leakage.

Time varying fluid activity is mainly constrained by short-duration (100 kyr) and longduration (around $1 \mathrm{Myr}$ ) sedimentary cycles as demonstrated by the occurence of pockmarks at the sub-units (Fig. 6) and units (Fig. 5) scales. However, the interpretation of HAAF, HAAD and HAAC in term of carbonate buildups with various degrees of developpement suggests upward fluid flux variations. Regarding fluid flow, a detailed evolutionary sequence of fluidrelated features is proposed from an initial stage with various flux rates and the different stages depending on the dynamics of fluid flow (Fig. 19); this hypothetical scenario integrates the genetic relationship shown through geometric analysis on seismics coupled with the interpretation of amplitude variations in the same way as proposed by other conceptual models (Betzler et al., 2011; Gay et al., 2012; Ho et al., 2012; Sultan et al., 2007; Casenave et al. 2017).

Low flux rate: Initiation of fluid flow with low flux rate $(A)$ leads to the formation of carbonate crusts (methane-derived authigenic precipitations with small chemosynthetic fauna accumulations, i.e. HAAF) (B). Successive paleo-fluid flow locations and associated depressions of non depositional type result from successive seep events from UH6 to UH4 (C). The lateral extent of these crusts suggests several seep points migrating laterally for gas escape and linked to the same seep site. Then two alternatives are possible: (D1) some drains dry up and lead to a halt in gas escape and consequently to the progressive sealing 
and burying of the NDD-HAAF by the overlying sub-unit; (D2) other drains continue to seep with a constant but less active flux and lead to gas hydrate formation. Then (E2), and only in some places, a decrease in fluid flux triggers gas hydrate destabilisation (dissolution) and the sediment collapse as suggested by the presence of erosional depressions with relict HAAF and sedimentary infill (i.e. at UH3 and UH2 tops). Finally (F2), the seep site is abandoned and the ED-HAAF are progressively sealed by overlying sub-units.

Moderate flux rate. Moderate flow (A) leads to the genesis of carbonate domes formed by authigenic and chemoherm accumulations (HAAD) which follow the same sequence (B to F2) as for the HAAF. However, the inactive fluid period that follows ( $\mathrm{G} 2$ to $\mathrm{H} 2$ ) may lead to the dissolution of gas hydrates to form the shallow ring-shaped ED-HAAP on the seafloor and then the deep irregular-shaped ED over time after sediment collapse. These gas hydrates are supposedly to have formed above the buried NDD-HAAD as suggested by the geometries (G2) and preserved until their dissolution (F2).

High flux rate: constant and moderate to high fluid flow and seepage into the water column $(A)$ generate high elevations of carbonate build-ups over time linked to a high rate of authigenic and chemoherm accumulations (HAAC). These carbonate mounds terminate in near seafloor pockmarks through non deposition of hemipelagic sediments ( $B$ to F2). Most of these features tend to be currently buried, suggesting an overall decrease in fluid supply from a deeper level

\subsection{Spatial evolution}

Faults and discontinuities are responsible for focused seepage at the seafloor and pockmark formation (Abrams, 1992; Boe et al., 1998; Brown, 2000; Orange et al., 1999; 
Pilcher and Argent, 2007; De Prunelé et al., 2017) and seabed mound development (e.g. Hovland et al., 1994; see in Judd and Hovland, 2009).

Vertical fluid conduits commonly occur on parts of the Nigerian continental slope dominated by folding and faulting (Graue, 2000; Heegland et al., 2001; Leduc et al., 2013; Loseth et al., 2010) in response to rapid sedimentation rate and shale remobilization (e.g. Morley and Guerin, 1996). According to previous work in the study area (unpublished data), a first compressional phase generated a series of NW-SE oriented fold/thrusts such as the southern lineament. However, as evidenced by the presence of a graben, the top of the antiform is marked by an extensive phase. The NW-SE oriented normal faults and northern lineament are believed to accommodate the extrados of the folded layers above the thrust (Fig. 3). The second compressional phase generated a system of SW-NE oriented normal faults between the two thrusts crossing the region. From these observations, we interpret the grid pattern of very small SW-NE and NW-SE oriented structures located in the graben (Fig. 4, Fig. 5) as a complex faulting pattern linked to the bi-axial compression. In the same way that structural lineaments and major faults allow fluid migration, these small faults may play the role of potential drains supplying fluids from a buried reservoir.

According to the relationships between the different types of depressions and the different structures in the study area: the grid pattern of small faults and the larger faults in the graben seem to act as a network of ephemeral feeder structures, from $\mathrm{UH} 6$ to $\mathrm{UH} 4$, for the genesis of ephemeral pockmarks with carbonate crusts and gas hydrates and carbonate domes (NDD-HAAF and-HAAD). Structural lineaments and major faults are regarded to act as perennial feeder structures, from $\mathrm{UH} 6$ to $\mathrm{UH} 1$, for the genesis of perennial pockmarks with carbonate mounds (NDD-HAAC). Therefore, we propose that the type of fault controls the variation of flux rate and consequently the type of pockmark (Fig. 19). The spatial distribution of the different types of faults controls the spatial arrangement of the different types of pockmarks. 
Regarding the activity of faults, the short (100 kyr) and long (1 Myr) term cyclic evolution of fluid flux implies a cyclic fracturing/resealing process as reactivation of fracturing is necessary to provoke the occurrence of a new generation of seep features after sealing.

\section{Conclusion}

The analyses of multi-scale and complementary geophysical datasets, coupled with ground information, have provided insights into the origin, subsequent flow and sedimentary dynamics, and role of faults on fluid-related features and their spatio-temporal distribution in deep water Nigeria.

- The fluid-related features show a set of depressions of varied morphology and associated seismic anomalies. They result in the disturbance of hosting sediments through two main processes: (1) no or low deposition of sediments, caused by upward fluid seapage into the water column and subsequent seafloor settlement (benthic faunal activity, carbonate precipitation, gas hydrate formation) and (2) post-depositional erosion, caused either by fluid release (e.g. dewatering from underlying features such as channels) or by collapse (destabilisation of gas hydrates).

- The various degrees of flux intensity may explain the different categories of fluid-related features such as ephemeral or perennial methane-derived carbonates (authigenic precipitations or chemosynthetis fauna accumulations). The additional effect of gas hydrate dynamics may explain the formation of depressions related to a hypothetical destabilisation of gas hydrates, likely dissolution in response to changes in the rate of fluid flow.

- The subsurface network of faults, in relation to deep structures, is an important factor in the determination of the nature of fluid-related features. Depressions with 
carbonate build-ups are mainly concentrated above major faults (mainly fold or thrust faults) whereas most of the depressions related to gas hydrate dissolution are observed above small faults.

- The rate of fluid flow is suspected to be constrained by long term Turbidite/Hemipelagic cycles (i.e. long duration stratigraphic sequence of Jermannaud et al., 2010). The fluid seeps develop almost exclusively during the hemipelagic phase and in accordance with a precise chronology of occurrence and growth. This non-random stratigraphic distribution defines two main stages: (1) a first stage corresponding to the most active "methane window". This period is characterised by strong fluid activity along fault planes with the formation of numerous pockmarks and carbonate build-ups; (2) a second stage marked by a decrease in fluid activity accompanied by increasingly scarce carbonate build-ups and destabilisation of gas hydrates. Other sedimentary processes occur such as dewatering from the channel-levees interface which can also generate pockmarks on the seafloor.

\section{Acknowledgements}

This work was supported by the Neris and ERIG3D projects (Collaboration between Total, D.H. Drapeau and Ifremer, M. Voisset). B. Marsset, N. Sultan, S. Garziglia, P. Vagner, E. Thereau, and H. Ondreas (Ifremer) are greatly thanked for their scientific and technical contribution. We would like to thank A. Chalm for the proof-reading of the text. We also thank TOTAL which provided reprocessed exploration 3D and C\& $C$ datasets.

Thanks are extended to the scientific staff and crew of Ifremer and GENAVIR who operated the ships (R/V Suroît, R/V Atalante, R/V Pourquoi Pas?) and equipment during expeditions at sea (Neris1, 2003; Neris2, 2004; ERIG3D, 2008). The authors wish to thank 


\section{ACCEPTED MANUSCRIPT}

the two anonymous reviewers for their comments and suggestions which have greatly improved the manuscript.

\section{References}

Abrams, M.A., 1992. Geophysical and geochemical evidence for subsurface hydrocarbon leakage in the Bering Sea, Alaska. Marine and Petroleum Geology 9, 208-221.

Arntsen, B., Wensaas, L., Løseth, H., Hermanrud, C., 2007. Seismic modelling of gas chimneys. Geophysics, 72: 251-259.

Bailey, W., Shannon, P.M., Walsh, J.J., Unnithan, V., 2003. The spatial distributions of faults and deep sea carbonate mounds in the Porcupine Basin, offshore Ireland. Marine and Petroleum Geology 20, 509-522.

Bayon, G., Pierre, C., Etoubleau, J., Voisset, M., Cauquil, E., Marsset, T., Sultan, N., Le Drezen, E., Fouquet, Y., 2007. Sr/Ca and $\mathrm{Mg} / \mathrm{Ca}$ ratios in Niger Delta sediments: implications for authigenic carbonate genesis in cold seep environments. Marine Geology 241, 93-109.

Bayon, G., Henderson, G.M., Etoubleau, J., Caprais, J.C., Ruffine, L., Marsset, T., Dennielou, B., Cauquil, E., Voisset, M., Sultan, N., 2015. U-Th isotope constraints on gas hydrate and pockmark dynamics at the Niger delta margin. Marine Geology 370, 87-98.

Betzler, C., Lindhorst, S., Hübscher, C., Lüdmann, T., Fürstenau, J., Reijmer, J., 2011. Giant pockmarks in a carbonate platform (Maldives, Indian Ocean). Marine Geology 289, 116.

Bilotti, F.D., Shaw, J.H., 2005. Deep-water Niger Delta fold and thrust belt modelled as a critical-taper wedge: The influence of elevated basal fluid pressure on structural styles. AAPG Bulletin 89, 11, 1475-1491. 
Boe, R., Rise, L. and Ottesen, D., 1998. Elongate depressions on the southern slope of the Nowegian trench (Skagerrak): morphology and evolution. Marine Geology 146, 191203.

Briggs, S.E., Davies, R.J., Cartwright, J.A., Morgan, R., 2006. Multiple detachment levels and their control on fold styles in the compressional domain of the deepwater west Niger Delta. Basin Research 18 (4), 435-450. doi:10.1111/j.1365-2117.2006.00300

Brooks, J.M., Bryant, W.R., Bernard, B.B., Cameron, N.R., 2000. The nature of gas hydrates on the Nigerian continental slope. Gas hydrates: challenges for the future. Annals of the New York Academy of Sciences 912, 76-93. DOI: 10.1111/j.1749-6632.2000.tb06761.x

Brown, A., 2000. Evaluation of possible gas microseepage mechanisms. AAPG Bulletin 84, 1775-1789.

Burke, K., 1972. Longshore drift, submarine canyons, and submarine fans in developments of the Niger Delta. AAPG Bulletin 56, 1975-1983.

Chand, S., Rise, L., Ottesen, D., Dolan, M.F.J., Bellec, V., Bøe, R., 2009. Pockmark-like depressions near the Goliat hydrocarbon field, Barents Sea: morphology and genesis. Marine and Petroleum Geology 26, 1035-1042.

Casenave V., Gay A., Imbert P. Spider structures: records of fluid venting from methane hydrates on the Congo continental slope. Bulletin de la Société Geologique de France, in press.

Cobbold, P., Clarke, B.J., Løseth, H., 2009. Structural consequences of fluid overpressure and seepage forces in the outer thrust belt of the Niger Delta. Petroleum Geoscience 15, 3-15.

Corredor, F., Shaw, J.H., Bilotti F., 2005. Structural styles in the deep-water fold and thrust belts of the Niger Delta. AAPG Bulletin 89, 6, 753-780.

Cunningham, R., Lindholm, R.M., 2000. Seismic evidence for wide extruded mud flows gas hydrate formation, Offshore West Africa. In: Mello, M.R., Katz, B.J. (Eds.), Petroleum systems of South Atlantic margins. AAPG Memoir 73, 93-105. 
Damuth, J.E., 1994. Neogene gravity tectonics and depositional processes on the deep Niger Delta continental margin. Marine and Petroleum Geology 11, 3, 320-346.

Davies, R.J., 2003. Kilometer-scale fluidization structures formed during early burial of a deep-water slope channel on the Niger Delta. Geology 31, 949-952.

Davy, B., Pecher, I., Wood, R., Carter, L., Gohl, K., 2010. Gas escape features off New Zealand: evidence of massive release of methane from hydrates. Geophysical Research Letters 37.

De Prunelé, A., Ruffine, L., Riboulot, V., Peters, C.A., . Guyader, V., Carnavallo, L., Bayon, G., Donval, J.P., Sultan, N., Caprais, J.C., Marsset, T., Pape, T., Bohrmann, G., Géli, L., Lescanne, M., Cauquil, E., 2017. Focused hydrocarbon-migration in shallow sediments of a pockmark cluster in the Niger Delta (Off Nigeria). Geochem. Geophys. Geosyst., 18, doi:10.1002/2016GC006554.

Dickinson, G., 1953. Geological aspects of abnormal reservoir pressures in Gulf Coast Louisiana. AAPG Bulletin 37, 410-432.

Dimitrov, L., Woodside, J., 2003. Deep sea pockmarks environments in the eastern Mediterranean. Marine Geology 195, 263-276.

Doust, H., Omatsola, E., 1990. Niger Delta. In: Edwards, J.D., Santogrossi, P.A. (Eds.), Divergent/passive margin basins. AAPG Memoir 48, 201-238.

Dumke, I., Berndt, C., Crutchley, G.J., Krause, S., Liebetrau, V., Gay, A., Couillard, M., 2014. Seal bypass at the Giant Gjallar Vent (Norvegian Sea): Indications for a new phase of fluid venting at a 56-Ma-old fluid migration system. Marine Geology, 351: 38-52.

Eichhubl, P., Greene, H.G., Naehr, T., Maher, N., 2000. Structural control of fluid flow: offshore fluid seepage in the Santa Barbara Basin, California. Journal of Geochemical Exploration 69/70, 545-549.

Evamy, B.D., Haremboure, J., Kamerling, P., Knapp, W., Molloy, F.A., Rowlands, P.H., 1978. Hydrocarbon habitat of Tertiary Niger Delta. AAPG Bulletin 62, 1-39. 
Fisher, C., 1997. Penn State Science, 1997, Scientists Discover Methane Ice Worms on Gulf of Mexico Sea Floor. Website: http://www.science.psu.edu/newsandevents/1997news/iceworms.htm.

Floodgate, G. D., Judd, A.G., 1992. The origins of shallow gas. Continental Shelf Research,12 (10), 1145-1156, doi:10.1016/0278-4343(92)90075-U

Forwick, M., Baeten, N.J., Vorren, T.O., 2009. Pockmarks in Spitsbergen fjords. Norwegian Journal of Geology 89, 65-77, ISSN 029-196X.

Gay, A., 2002. Les marqueurs géologiques de la migration et de l'expulsion des fluides sédimentaires sur le plancher des marges passives matures: exemples dans le bassin du Congo. PhD thesis. University of Lille 1, France.

Gay A., Lopez, M., Cochonat, P., Sultan, N., Cauquil, E., Brigaud, F., 2003. Sinuous pockmark belt as indicator of a shallow buried turbiditic channel on the lower slope of the Congo basin, West African margin. In: Van Rensbergen, P., Hillis, R., Maltman, A.J., Morley C.K. (Eds.), Subsurface sediment mobilization. Geological Society of London, special publications, 216, pp.173-189.

Gay, A., Lopez, M., Cochonat, P., Séranne, M., Levaché, D., Sermondadaz, G., 2006. Isolated seafloor pockmarks linked to BSRs, fluid chimneys, polygonal faults and stacked Oligocene-Miocene turbiditic palaeochannels in the Lower Congo Basin. Marine Geology 226, 25-40.

Gay, A., Lopez, M., Berndt, C., Séranne, M., 2007. Geological controls on focused fluid flow associated with seafloor seeps in the Lower Congo Basin. Marine Geology 244, 68-92.

Gay, A., Mourgues, R., Berndt, C., Bureau, D., Planke, S., Laurent, D., Gautier, S., Lauer, C., Loggia, D., 2012. Anatomy of a fluid pipe in the Norway Basin: Initiation, propagation and 3D shape. Marine Geology, 332-334, pp.75-88. <10.1016/j.margeo.2012.08.010>

Gay, A., Cavailhes, T., Grauls, D., Marsset, B., Marsset, T., 2017. Repeated fluid expulsions during events of rapid sea-level rise in the Gulf of Lion, western Mediterranean Sea. Bulletin de la Société Geologique de France, in press. 
George, R.A., Cauquil, E., 2007. AUV ultrahigh-resolution 3D seismic technique for detailed subsurface investigations. In: Offshore Technology Conference. Houston, TX, USA. OTC 18784

Graue, K., 2000. Mud volcanoes in deepwater Nigeria. Marine and Petroleum Geology 17, 959-974.

Greinert, J., Bohrmann, G., Suess, E., 2001. Gas hydrate-associated carbonates and methane venting at Hydrate Ridge: Classification, distribution and origin of carbonate lithologies. In: Paull, C.K., Dillon, W.P. (Eds.), Natural Gas Hydrates: Occurrence, Distribution and Detection. American Geophysical Union 124, 99-113.

Haack, R.C., Sundararaman, P., Diedjomahor J.O., Xiao, H., Gant, N.J., May, E.D., Kelsch, K., 2000. Niger delta petroleum systems, Nigeria. DOI: 10.1306/M73705C16 In: Mello, M.R., Katz, B.J. (Eds.), Petroleum Systems of South Atlantic Margins: AAPG Memoir 73, pp. 213-232 (Tulsa, Oklahoma). DOI: 10.1306/M73705

Haskell, N., Nissen, S., Hughes, M., Grindhaug, J., Dhanani, S., Heath, R., Kantorowicz, J., Antrim, L., Cubanski, M., Nataraj, R., Schilly, M., Wigger, S., 1999. Delineation of geologic drilling hazards using 3-D seismic attributes. The leading edge 18 (3), 373382.

Haq, U.B., Hardenbol, J., Vail, P.R., 1987. Chronology of fluctuating sea levels since the Triassic. Science 235, 1156-1167.

Hardenbol, J., Thierry, J., Farley, M.B., Jacquin, T., de Graciansky, P.C., Vail, P.R., 1998. Mezozoic and Cenozoic sequence chronostratigraphic framework of European basins. In: de Graciansky, P.C., Hardenbol, J., Jacquin, T., Vail., P.R., (Eds), MesozoicCenozoic Sequence Stratigraphy of European Basins, Society of Economic Paleontologists and Mineralogists Special Publications, 60. Tulsa OK: pp. 3-13, 763781, and chart supplements.

Heggland, R., Hovland, M., Graue, K., Gallagher, J.W., 2001. Mud volcanoes and gas hydrates on the Niger Delta Front. In: Conference Abstract Book: Subsurface Sediment Mobilization. University of Gent, Belgium. Sept, 44. 
Heggland, R., 2003. Vertical Hydrocarbon Migration at the Nigerian Continental Slope: Applications of Seismic Mapping Techniques. AAPG Annual Convention, Salt Lake City, May 11-14.

Higgins, S., Clarke, B., Davies, R.J., Cartwright, J., 2009. Internal geometry and growth history of a thrust-related anticline in a deep water fold belt. Journal of Structural Geology 31 (12), 1597-1611.

Hjelstuen B.O., Haflidason, H., Sejrup, H.P., Nygard, A., 2010. Sedimentary and structural control pockmark development - evidence from the Nyegga pockmark field, NW European margin. Geo-Marine Letters 30, 221-230. DOI 10.1007/s00367-009-0172-4

Ho, S., Cartwright, J.A., Imbert, P., 2012. Vertical evolution of fluid venting structures in relation to gas flux, in the Neogene-Quaternary of the Lower Congo Basin, Offshore Angola. Marine Geology 332-334, 40-55

Homewood, P., Guillocheau, F., Eschard, R., Cross, T., 1992. Corrélation haute résolution et stratigraphie génétique: une démarche intégrée. Bulletin des Centres de Recherches Exploration-Production Elf-Aquitaine 16, 375-381.

Homewood, P., Mauriaud, P., Lafont, F., 1999. Best Practices in Sequence Stratigraphy for Explorationists and Reservoir Engineers. Elf Exploration Edition Memoir, Pau, 80 pp.

Hooper, R.J., Fitzsimmons, R.J., Grant, N., Vendeville, B.C., 2002. The role of deformation in controlling depositional patterns in the south-central Niger Delta, West Africa. Journal of Structural Geology 24, 847-859.

Hovland, M., 1981. Characteristics of pockmarks in the Norwegian trench. Marine Geology $39,103-117$.

Hovland, M., Judd, A.G., King, L.H.,1984. Characteristic features of pockmarks on the North Sea Floor and Scotian Shelf. Sedimentology 31, 471-480.

Hovland, M., Judd, A.G., 1988. Seabed pockmarks and Seepages: Impact on Geology, Biology and the Marine Environment. In: Graham and Trotman (Eds.), London, 293 pp. 
Hovland, M., Croker, P.F., Martin, M., 1994. Fault-associated seabed mounds (carbonate knolls?) off western Ireland and north-west Australia. Marine and Petroleum Geology $11,232-246$.

Hovland, M., 2002. On the self-sealing nature of marine seeps. Continental Shelf Research $22(16), 2387-2394$.

Hovland,M., Svensen, H., Forsberg, C.F., Johansen, H., Fichler, C., Fossa, J.H., Jonsson, R., Rueslatten, H., 2005. Complex pockmarks with carbonate-ridges off mid-Norway: products of sediment degassing. Marine Geology 218, 191-206. http://dx.doi.org/10.1016/j.margeo.2005.04.005

Hunt, J.M., 1990. Generation and migration of petroleum from abnormally pressured fluid compartments: AAPG Bulletin 74, 1-12.

Jermannaud, P., Rouby, D., Robin, C., Nalpas, T., Guillocheau, F., Raillard, S. 2010. PlioPleistocene sequence stratigraphic architecture of the eastern Niger Delta: a record of eustasy and aridification of Africa. Marine and Petroleum Geology 27 (4), 810-821. doi:10.1016/j.marpetgeo.2009.12.005

Judd, A., Hovland, M., 2009. Seabed Fluid Flow: the Impact on Geology, Biology and the Marine Environment. Cambridge University Press.

Karisiddaiah, S.M., Veerayya, M., 2002. Occurrence of pockmarks and gas seepages along the central western continental margin of India. Current Sciences 82, 1, 52-56.

Kastner, M., Claypool, G., Robertson, G., 2008. Geochemical constraints on the origin of the pore fluids and gas hydrate distribution at Atwater Valley and Keathley Canyon, northern Gulf of Mexico. Marine and Petroleum Geology 25, 860-872.

Ker, S., Marsset, B., Garziglia, S., Le Gonidec, Y., Gibert, D., Voisset, M., Adamy, J., 2010. High-resolution seismic imaging in deep sea from a joint deep-towed/OBH reflection experiment: application to a Mass Transport Complex offshore Nigeria. Geophysical Journal International 182, 3, 1524-1542 DOI: 10.1111/j.1365-246X.2010.04700.x

Knox, G.J., Omatsola, E.M., 1988. Development of the Cenozoic Niger delta in terms of the "escalator regression" model and impact on hydrocarbon distribution. Koninklijk 
Nederlands Geologisch en Mijnbouwkundig Gezelschap Symposium on Coastal Lowlands, Geology and Geotechnology Proceeding (1987). Klower Academic Publishers, Dortrecht, Netherland, 181-202.

Kopf, A.J., 2002. Significance of mud volcanism. Review of Geophysics 40, 2.

Leduc, A.M., Davies, R.J., Swarbrick, R.E, Imber, J., 2013. Fluid flow pipes triggered by lateral pressure transfer in the deepwater western Niger Delta. Marine and Petroleum Geology 43, 423-433.

León, R., Somoza, L., Medialdea, T., Maestro, A., Diaz-del-Rio, V., Fernandez-Puga, M.C., 2006. Classification of seafloor features associated with methane seeps along the Gulf of Cadiz continental margin. Deep-Sea Research II 53, 1464-1481.

León R., Somoza L., Medialdea T., Hernández-Molina F.J., Vázquez J.T., Díaz-del-Rio V., González F.J., 2010. Pockmarks, collapses and blind valleys in the Gulf of Cádiz. GeoMarine Letters 30 (3/4), 231-247.

Løseth, H.,Wensaas, L., Arntsen, B., Hanken, N.-M., Basire, C., Graue, K., 2011. 1000 m long gas blow-out pipes. Marine and Petroleum Geology 28 (5), 1047-1060.

MacDonald, G.J., 1990. Role of methane clathrates in past and future climates. Climate Change 16, 247-281.

Mackenzie, A. S., Quigley, T. M., 1988. Principles of geochemical prospect appraisal. AAPG Bulletin 72, 399-415.

Maloney, D., Davies, R.J., Imber, J., Higgins, S., King, S., 2010. New insights into deformation mechanisms in the gravitationally driven Niger Delta deep-water fold and thrust belt. AAPG Bulletin 94 (9), 1401-1424.

Marcon Y., Ondréas, H., Sahling H., Bohrmann, G., Olu, K., 2014. Fluid flow regimes and growth of a giant pockmark. Geology 42, 63-66. doi: 10.1130/G34801.1.

Marsset, T., Marsset, B., Ker, S., Thomas, Y., Le Gall, Y., 2010. High and very resolution deep-towed seismic system: performance and examples from deep water geohazard studies. Deep Sea Research I 57, 628-637. 
Mazzini, A., Ivanov, M.K., Nermoen, A., Bahr, A., Bohrmann, G., Svensen, H., Planke, S., 2008. Complex plumbing systems in the near subsurface: Geometries of authigenic carbonates from Dolgovskoy Mound (Black Sea) constrained by analogue experiments. Marine and Petroleum Geology 25, 457-472.

Moss, J.L., Cartwright, J., 2010. 3D seismic expression of km-scale fluid escape pipes from offshore Namibia. Basin Research 22, 481-501.

Moss, J.L., Cartwright, J. Cartwright, A., Moore, R., 2012. The spatial pattern and drainage cell characteristics of a pockmark field, Nile Deep Sea Fan. Marine and Petroleum Geology 35, 321-336. http://dx.doi.org/10.1016/j.marpetgeo.2012.02.019

Merki, P., 1972. Structural geology of the Cenozoic Niger delta. In: Dessauvagie, T.F., Whiteman, A.J. (Eds.), African Geology. University of Ibadan, Nigeria, pp. 635646.Mitchum, R.M., Vail, P.R., Sangree, J.B., 1977. Seismic stratigraphy and global changes in sea-level, part 6: stratigraphic interpretation of seismic reflection patterns in depositional sequences. In: Seismic stratigraphy - Application to Hydrocarbon Exploration (Ed. C.E. Payton), AAPG Memoir 26, 117-133.

Morgan, R., 2003. Prospectivity in ultradeep water: the case for petroleum generation and migration within the outer parts of the Niger Delta Apron. In: Arthur, M.A., MacGregor, D.S., Cameron, N.R. (Eds.), Petroleum Geology of Africa: New Themes and Developing Technologies. Geological Society Special Publications 207, London, pp. 151-164.

Morley, C.K., Guerin, G., 1996. Comparison of gravity driven deformation styles and behaviour associated with mobile shales and salt. Tectonics 15 (6), 1154-1170.

Mourgues, R., Lecomte, E., Vendeville, B., Raillard, S., 2009. An experimental investigation of gravity-driven shale tectonics in progradational delta. Tectonophysics 474 (3-4), 643656.

Niewöhner, C., Hensen, C., Kasten, S., Zabel, M., Schulz, H.D., 1998. Deep sulphate reduction completely mediated by anaerobic methane oxidation in sediments of the upwelling area off Namibia. Geochimica Cosmochimica Acta 62 (3), 455-464. 
Ondreas, H., Olu, K., Fouquet, Y., Charlou, J., Gay, A., Dennielou, B., Donval, J., Fifis, A., Nadalig, T., Cochonat, P., Cauquil, E., Bourillet, J., Moigne, M., Sibuet, M., 2005. ROV study of a giant pockmark on the Gabon continental margin. Geo-Marine Letters 25, 281.

Orange, D.L., Greene, H.G., Reed, D., Martin, J.B., McHugh, C.M., Ryan, W.B.F., Maher, N., Stakes, D. \& Barry, J. 1999. Widespread fluid expulsion on a translational continental margin: Mud volcanoes, fault zones, headless canyons, and organic-rich substrate in Monterey Bay, California. Geological Society of America Bulletin 111, 992-1009.

Ostanin, I., Anka, Z., di Primio, R., Bernal, A., 2013. Hydrocarbon plumbing systems above the Snøhvit gas field: Structural control and implications for thermogenic methane leakage in the Hammerfest Basin, SW Barents Sea. Marine and Petroleum Geology 43, 127-146.

Pastouret, L., Melguen, M., Thiede, J., 1980. Sédimentation pleistocène dans le Golfe de Guinée. Comparaison des données micropaléontologiques et sédimentologiques: Actes du Vle colloque Africain de Micropaléontologie, Tunis 1974, Annale des Mines et de la Géologie, Tunis, 28 (3) 369-386.

Pau, M., Hammer, O., Chand, S., 2014. Constraints on the dynamics of pockmarks in the SW Barents Sea: Evidence from gravity coring and high-resolution, shallow seismic profiles. Marine Geology 355, 330-345.

Pilcher, R., Argent, J., 2007. Mega-pockmark sand linear pockmark trains on the West African continental margin. Marine Geology 244 (1-4), 15-32.

Reeburgh, W.S., 1976. Methane consumption in Cariaco Trench waters and sediments. Earth and Planetary Sciences Letters 28, 337-344.

Riboulot, V., 2011. Facteurs de contrôle du fonctionnement des pockmarks durant les derniers cycles climatiques (Partie orientale du delta sous-marin du Niger et Golfe du Lion), PhD thesis, Université of Perpignan, France, 243 pp.

Riboulot, V., Cattaneo, A., Sultan, N., Garziglia, S., Ker, S., Imbert, P., Voisset, M., 2013. Sea-level change and free gas occurrence influencing a submarine landslide and 
pockmark formation and distribution in deepwater Nigeria. Earth and Planetary Science Letters 375, 78-91.

Riboulot V., Sultan, N., Imbert, P., Ker, S., 2016. Initiation of gas-hydrate pockmark in deepwater Nigeria: Geo-mechanical analysis and modelling. Earth and Planetary Science Letters 434, 252-263. doi:10.1016/j.epsl.2015.11.047

Roberts, H.H., 2001. Fluid and Gas Expulsion on the Northern Gulf of Mexico Continental Slope: Mud-prone to Mineral-prone Responses. Washington, DC, ETATS-UNIS, American Geophysical Union, p. 322.

Rollet, N., Logan, G.A., Kennard, J.M., O'Brien, P.E., Jones, A.T., Sexton, M., 2006. Characterisation and correlation of active hydrocarbon seepage using geophysical data sets: An example from the tropical, carbonate Yampi Shelf, Northwest Australia. Marine and Petroleum Geology 23 (2), 145-164.

Rongemaille, E., Bayon, G., Pierre, C., Bollinger, C., Chu, N.C., Fouquet, Y., Riboulot, V., Voisset, M., 2011. Rare earth elements in cold seep carbonates from the Niger delta. Chemical Geology 286, 196-206.

Rouby, D., Nalpas T., Jermannaud P., Robin C., Guillocheau F., Raillard S., 2011. Gravity driven deformation controlled by the migration of the delta front: The Plio-Pleistocene of the Eastern Niger Delta. Tectonophysics 513, 54-67.

Ruffine, L., Caprais, J.C., Bayon, G., Riboulot, V., Donval, J.P., Etoubleau, J., Birot, D., Pignet, P., Rongemaille, E., Chazallon, B., Grimaud, S., Adamy, J., Charlou, J.L., Voisset, M. , 2013. Investigation on the geochemical dynamics of a hydrate-bearing pockmark in the Niger Delta. Marine and Petroleum Geology 43, 297-309. http://dx.doi.org/10.1016/j.marpetgeo.2013.01.008

Saugy, L., Eyer, J.A., 2003. Fifty years of exploration in the Niger Delta (West Africa). In: Halbouty, M.T. (Ed.), Giant Oil and Gas Fields of the Decade 1990-1999: AAPG memoir 78, pp. 211-226.

Short, K.C., Stauble, A.J., 1967. Outline of geology of Niger delta. AAPG Bulletin 15 (5), 761779. 
Snyder, G.T., Hiruta, A., Matsumoto, R., Dickens, G.R., Tomaru, H., Takeuchi, R., Komatsubara, J., Ishida, Y., Yu, H., 2007. Pore water profiles and authigenic mineralization in shallow marine sediments above the methane-charged system on Umitaka Spur, Japan Sea. Deep Sea Research Part II: Topical Studies in Oceanography 54, 1216-1239.

Soter, S., 1999. Macroscopic seismic anomalies and submarine pockmarks in the CorinthPatras rift, Greece. Tectonophysics 308, 275-290.

Stacher, P., 1995. Present understanding of the Niger Delta hydrocarbon habitat. In: M.N. Oti, G., Postma (Eds.), Geology of deltas, pp. 257-257.

Suess, E., 2014. Marine cold seeps and their manifestations: geological control, biogeochemical criteria and environmental conditions. International Journal of Earth Sciences 103, 1889-1916. DOI 10.1007/s00531-014-1010-0

Sultan, N., Bohrmann, G., Ruffine, L., Pape, T., Riboulot, V., Colliat, J.L., De Prunelé, A., Dennielou, B., Garziglia, S., Himmler, T., 2014. Pockmark formation and evolution in deep water Nigeria: rapid hydrate growth versus slow hydrate dissolution. Journal of Geophysical Research, Solid Earth 119, 2679-2694.

Sultan, N., Marsset, B., Ker, S., Marsset, T., Voisset, M., Vernant, A.M., Bayon, G., Cauquil, E., Adamy, J., Colliat, J.L., Drapeau, D., 2010. Hydrate dissolution as a potential mechanism for pockmark formation in the Niger delta. Journal of geophysical research 115, B08101. doi:10.1029/2010JB007453

Sultan, N., Riboulot, V., Ker, S., Marsset, B., Geli, L., Tary, J.B., Klingelhoefer, F., Voisset, M., Lanfumey, V., Colliat, J.L., Adamy, J ., Grimaud S., 2011. Dynamics of fault-fluidhydrate system around a shale-cored anticline in deepwater Nigeria. Journal of geophysical research 116, B12110, http://dx.doi.org/ 10.1029/2011JB008218.

Sultan, N., Voisset, M., Marsset, T., Vernant, A.M., Cauquil, E., Colliat, J.L., Curinier, V., 2007. Detection of free gas and gas hydrate based on 3D seismic data and cone 
penetration testing: an example from the Nigerian Continental Slope. Marine Geology $240,235-255$.

Swarbrick, R.E., Osborne, M.J., 1998. Mechanisms that generate abnormal pressures: an overview. In: Law, B.E., Ulmishek, G.F., Slavin, V.I. (Eds.), Abnormal Pressures in Hydrocarbon Environments, AAPG Memoir 70, Tulsa, OK, pp. 13-34.

Vogt, P.R., Gardner, J., Krane, K., 1999. The Norwegian-Barents-Svalbard (NBS) continental margin: Introducing a natural laboratory of mass wasting, hydrates, and ascent of sediment, pore water, and methane. Geo-Marine Letters 19, 2-21.

Weber, K.J., Daukoru, E.M., 1975. Petroleum geological aspects of the Niger Delta. Nigeria Journal of Mineralogy and Geology 12, 9-32.

Wiener, R.W., Mann, M.G., Advocate, D.M., Angelich, M.T., Barboza, S.A., 2006. Mobile shale characteristics and impact on structural and stratigraphic evolution of the Niger Delta. In: Proceedings of the AAPG/GSTT Hedberg Conference, Port of Spain, Trinidad, Tobago.

Whiteman, A., 1982. Nigeria: Its Petroleum Geology, Resources and Potential. Graham \& Trotman, London, $382 \mathrm{pp}$.

Wu, S., Bally, A.W., 2000. Slope tectonics-comparisons and contrasts of structural styles of salt and shale tectonics of the northern Gulf of Mexico with shale tectonics of offshore Nigeria in Gulf of Guinea. In: Mohriak, W., Talwani, M. (Eds.), Atlantic Rifts and Continental Margins. American Geophysical Union Geophysical Monograph Series $115,151-172$

Yahaha, J.U., Okikiade, F., Ghosh, D.P., Snepco, 2000. Geohazard analysis in deepwater Nigeria. OTC 11924.

Zabel, M., Schneider, R.R., Wagner, T., Adegbie, A.T., de Vries, U., Kolonic, S., 2001. Late Quaternary Climate Changes in Central Africa as Inferred from terrigenous input to the Niger Fan. Quaternary Research 56, 207-217. 


\section{Figure captions}

Fig. 1. Tectono-sedimentary context of the Niger Delta. (A) Structural map of the Niger Delta. The study area is located in the black box. (B) Location of the Niger Delta and progradation of the delta over the Cenozoic; LME = Lower Middle Eocene; UME = Upper Middle Eocene; UUE = Upper Upper Eocene; Oli = Oligocene; O/M = Oligo-Miocene; Mio = Miocene; UM/P= Upper Miocene-Pliocene; P/P = Plio-Pleistocene. (C) Synthetic cross-section C of the Niger Delta. B is from Short and Stauble (1967). C is modified from Saugy and Eyer (2003). Extracted from Rouby et al., 2011.

Fig. 2. Typology of depressions. The typology is based on the morphology and seismic characteristics (geometry, facies) of depressions and their associated High Amplitude Anomalies (HAA). A) Non Depositional Depression (NDD). The single NDD is associated with HAA of flat shape (i.e. Single NDD-HAAF). The stacked NDD consist of a superposition of several single NDD and either their associated HAAF (NDD-HAAF) or their HAA amalgamated in a dome or a cone shape (NDD-HAAD or -HAAC). The NDD correspond to the tops of sub-units. Note the downward bending of reflectors of sub-units that indicate the thinning of hosting sediments around seismic anomalies and the depositional hiatus in the depression centre B) Erosional Depression (ED). The irregular-shaped depressions are either shallow and ring shaped and are associated with patch-shaped HAA (Ring ED-HAAP) or deep and associated with HAA of flat or dome-shape (ED-HAAF or -HAAD). The Vshaped ED is very deep and wide and the train ED are small and aligned. Note for all ED the truncation of reflectors (dashed line) on sidewalls and the filling configuration over the HAA. See detailed description in the text.

Fig . 3. Geomorphology of the study area. A) Bathymetric map of the study area based on Autonomous Underwater Vehicle (AUV) data (George and Cauquil, 2007), with location of 
SYSIF (SYstème SIsmique Fond) profiles. Note the distribution of fluid flow features within a NW-SE trending graben bound by the two structural northern (NL) and southern (SL) lineaments. The recent N-S trending buried channels recognized between 80 and $180 \mathrm{~ms}$ two-way travel time (ms twt) below the seabed and the major faults are projected on the map (extracted from Sultan et al., 2014). Pockmarks A, B, C1, C2, C3, Peanut and giant are labelled in accordance with previous studies. B) 3D line corresponding to the hull mounted sub-bottom profiler line $\mathrm{N} 1-\mathrm{CH} 05$ (see location on Fig. 3A) showing a graben, with faults, bound by NL and SL at the top of the structural antiform. Modified from Sultan et al., 2007.

Fig. 4. Tectonic and sedimentary features in the study area A) Random line extracted from the 3D volume showing the location of layers at respectively 150, 300 and $450 \mathrm{~ms}$ twt below seafloor (bsf). Note the location of the giant pockmark and the deep-rooted transparent anomalies underneath. B) Seabed seismic bathymetry and the three layers (coherence attribute) in orange, blue and green. C) Synthetic map showing the main features observed at the different depths with corresponding colour. Note the network of structures in red, blue and green (interpreted faults) around the graben and the grid pattern of very small SW-NE and NW-SE oriented structures (interpreted faulting pattern) within the graben.

Fig. 5. Seismic units, facies and structures identified in the sediment record along the graben axis. A) 3D line (for location see Fig. 3) corresponding to the SYSIF profile SYS01-HR-Pr02 (Fig. 6) and B) interpretative line drawing showing the main types of seismic units (UH, interpreted Hemipelagic phase, and UT, interpreted Turbidite phase), the high amplitude R reflector, high amplitude seismic anomalies (e.g. bright spots) and their location above seismic structures including superposed offsets of reflectors (interpreted faults) and stacked seismic anomalies. Note the draping seismic facies within UH except at the bright spot locations where a thinning of unit is observed. Note the three Pockmarks B (topographic low related to a paleo-depression), C1 (shallow ring-shaped ED) and C2 (NDD-HAAC). Note the 
two recent channels within UT (see Fig. 3A) and the oldest channels within UT (see Fig. 4C). Note the re-occurrence of bright spots within $\mathrm{UH}$ units.

Fig. 6. Seismic sub-units and depressions within the youngest UH unit. A) SYSIF profile SYS01-HR-Pr02 (for location see Fig. 3) and B) Interpretative line drawing showing the seismic sub-units and the different types of depressions and their associated seismic anomalies (ED-HAAD, NDD-HAAC etc.) with reference to the figure number for the definition and description of acronyms used in this study.

Fig. 7. Relationships between hosting sub-units and depressions. The SYSIF profile SYS01HR-Pr01 (for location see Fig. 3) and overlapped interpretative line drawing shows the abundance of depressions between $\mathrm{UH} 6$ and UH4, the marked depressions of NDD-HAAF tops at the top of $\mathrm{UH} 4$ and the lateral transition from the low-amplitude reflectors of hosting sediments to the NDD-HAAF. Note the preferential occurrence of depressions within UH units and the poor morphological expression of the channel. Note the possible stacked offsets of reflectors (interpreted fluid migration pathways) beneath the NDD-HAAF and their absence over these features.

Fig. 8. Non Depositional Depressions (NDD). A) SYSIF sections and their interpretative line drawing illustrating the different types of NDD (NDD-HAAF, -HAAD and -HAAC). Dotted colored lines on the seismic sections correspond to the sub-units tops. The Single NDDHAAF shows the depression related to the thinning of hosting sediments around seismic anomalies and draping facies (reflectors parallel to the underlying topography) above the depression (case 1). Note for NDD HAAF, the stacked NDD with their stacked HAAF (case 2). Note for NDD-HAAD the dome-shaped HAA associated with UH6 and UH5 (case 3). Note for NDD-HAAC the cone-shaped HAA associated with UH6 to UH2 (case 4), the shifts of anomalies suggesting shifts of fluid flow (black arrows, cases 4 and 5) indicative of a polyphased build-up of the structure. See on the left the small section crossing the Regab 
pockmark (unpublished WACS data) for comparison with NDD-HAAF. B) Distribution of NDD on the AUV bathymetric map. Note that contrary to NDD-HAAD (in orange) and NDD-HAAC (in brown), the NDD-HAAF (in yellow) do not, or weakly, impact the seafloor.

Fig. 9. Extent of NDD-HAAC in the NE of the study area. A) SYSIF section showing the elongated shape of the HAAC along the NW-SE direction (case 6 on Fig. 8B). The filling facies (onlaping reflectors) between the irregularities of the HAAC top marks the progressive sealing of abandoned structures. B) SYSIF section showing the narrow shape of NDD-HAAC on the cross section (case 7 on Fig. 8B). Note the acoustic mask below the NDD-HAAC.

Fig. 10. Erosional Depressions (ED). A) SYSIF sections showing different types of irregularshaped ED. Dotted colored lines on the seismic sections correspond to the sub-units tops. Dotted lines on the line drawing correspond to erosional surfaces (reflector truncation). Note for ED-HAAF and ED-HAAD (cases 8 and 9): the deep-buried ED and their crater shape, the reflector truncation on the depression sidewalls and the HAAF and HAAD in their centre (possible relic HAAF and HAAD of paleo-NDD), the filling facies attributed to collapsed sediments and, above this filling, the draping configuration which seals the depressions. Note the impact of these buried depressions on the seafloor. Note for Ring ED-HAAP the shallow erosional surface of ED on the seabed and the outcrop of the HAAP. The presence of a paleo-NDD is suspected bellow this feature (Case 10). B) Location of these ED on the AUV bathymetric map. Note the ring shape of ED.

Fig. 11. Deep erosional depressions on the seafloor. A) SYSIF cross sections and their interpretative line drawing illustrating a deep irregular-shaped ED on the seafloor. Note the absence of marked HAA in the depression but the presence of unstructured sediments in the centre (interpreted collapse material). Note on profile Sy02-PR08 the presence of two deep paleo-ED beneath the present one on the seafloor and the impact of this inherited topography on its structure (peanut shape on Fig. 11B). Note the truncation of reflectors on 
the sidewalls of all paleo-ED and the presence of an interpreted relic ED-HAAD bellow the oldest paleo-ED. B) Location on the AUV bathymetry.

Fig. 12. Giant V-shaped erosional depression. A) SYSIF section showing the V-shaped ED (pockmark giant). Note the reflector truncation. B) Location on AUV bathymetry.

Fig. 13. Trains of erosional depressions. A) Trains of small ED on AUV bathymetry (related to a channel, in yellow, and to a fault, in red). B) SYSIF section showing two trains of ED (related to a channel but only one train is clearly visible on the AUV map) characterised by a basal erosional surface (truncation of reflectors).

Fig. 14. Topographic lows related to paleo-depressions A) Distribution on AUV bathymetry. B) SYSIF sections showing the topographic low over a buried NDD-HAAD. The sedimentary draping over the abandoned NDD explains the absence of marked HAA on the seabed (cases 15 and 16).

Fig. 15. Topography inherited from stacked paleo-depressions. SYSIF section showing the influence of the topography inherited from a vertical sequence of buried NDD and ED on the seafloor. Note the NDD-HAAD at the base associated with UH6 to UH4, then the two deep irregular-shaped ED respectively associated with $\mathrm{UH} 3$ and $\mathrm{UH} 2$ capped by the draping (UH1) that seals the sequence top. See within UH1 the stacked enhanced reflections that may correspond to seep trails (Zoom). Note the topographic low with sediment instability on the seafloor. Dashed lines indicate erosional surfaces (truncation of reflectors). Note the wide extent of erosional surfaces at the top of $\mathrm{UH} 6$ to $\mathrm{UH} 2$.

Fig. 16. Spatio-temporal distribution of types of depressions within UH with respect to tectonic structures. The figure illustrates the wide diversity of depression types and evidences the risk of proposing an incorrect interpretation of features if their analysis is only 
based on their morphology from bathymetry. Note the location of features within the graben and on the northern (NL) and southern (SL) structural lineaments.

Fig. 17. Mapping of NDD-HAAC within UH A) Hull mounted sub-bottom profiler line N1CH05 showing the location of core N1-KS22 that allowed the calibration of seismic anomalies in pockmark E (HAAC i.e. chemoherm carbonates from Bayon et al. (2007). B) 3D line corresponding to $\mathrm{N} 1 \mathrm{CH} 05$ and showing the correlation between $\mathrm{HAAC}$ and bright spots. This profile illustrates the measurement of $\mathrm{UH}$ thickness variations (between the seafloor and the red horizon). C) Map of UH thickness variations. Small 3D sections are reported on the map at bright spots. Note, in blue, the depositional hiatus within the giant pockmark and peanut (V-shaped ED and deep irregular-shaped ED respectively) and at pockmarks E and C2 (bright spots i.e. NDD-HAAC). On the contrary, note, in beige, the full UH thickness of deposits within pockmark B (topographic low related to a paleo-depression). Then note, in green, intermediate values of UH thickness variations at pockmarks $A$ and $\mathrm{C} 1$ (shallow ringshaped ED). Structural NL and SL (in red) are projected on the map from Fig. 3.

Fig. 18. Distribution of AUV echo-facies and correlation with the different types of HAA within UH. A) AUV sub-bottom profiler line showing the various echo-facies and the location of the core Neris1 N1-KS22. B) Map of AUV echo facies. The acoustically turbid zones on AUV map (medium grey) correspond to the HAAF, HAAD and the High amplitude parabolic reflectors (dark grey) and outcrop (black) to our HAAC and HAAP on SYSIF. The HAAC (interpreted carbonate build-ups) identified on the 3D seismic by the bright spots and reported on the map of AUV echo-facies (dotted polygons) allowing to distinguish between the HAAC and HAAP.

Fig. 19. Hypothetical scenario of the evolution of different fluid flow features during the hemipelagic $(H)$ phase, depending on the dynamics of flow (intensity and continuity) at site location in relation to the type of fault (small fault, fault, major fault). All sites generate 
methane-derived pockmarks (A to $\mathrm{C}$ ), the flux intensity defining the character (ephemeral or perennial) of these pockmarks and their characteristics: low fluid flow generates carbonate crusts (NDD-HAAF) at small faults, moderate fluid generates carbonate domes (NDD-HAAD) at faults and high fluid flow generates carbonate mounds (NDD-HAAC) at major faults. For low and moderate fluid flow (small faults and faults), a decrease in the flux, and the interaction with later sedimentation favour hydrate formation within sediment layers in Gas Hydrate Stability Zone (D2). Then, hydrate destabilisation (dissolution ?) induces sediment liquefaction and expulsion to create collapse depressions (E2 and F2, ED-HAAF or ED$\mathrm{HAAD}$ ). Formation and destabilisation of $\mathrm{GH}$ is possibly recurrent. Currently, dissolution of gas hydrates appears near the seafloor leading to the formation of pockmarks, Ring EDHAAP, followed by deep irregular-shaped ED through time. See detailed description in the text. 

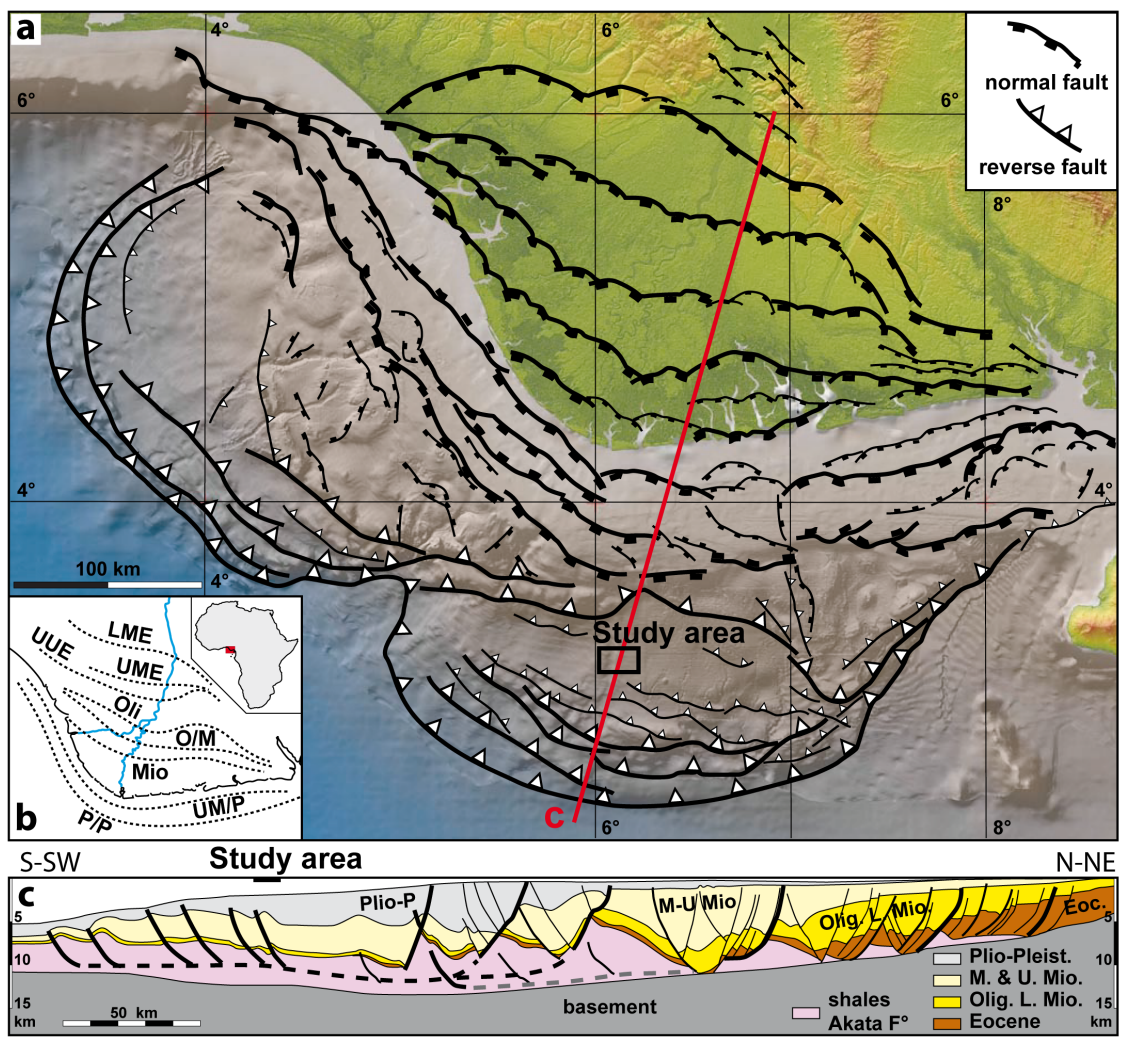


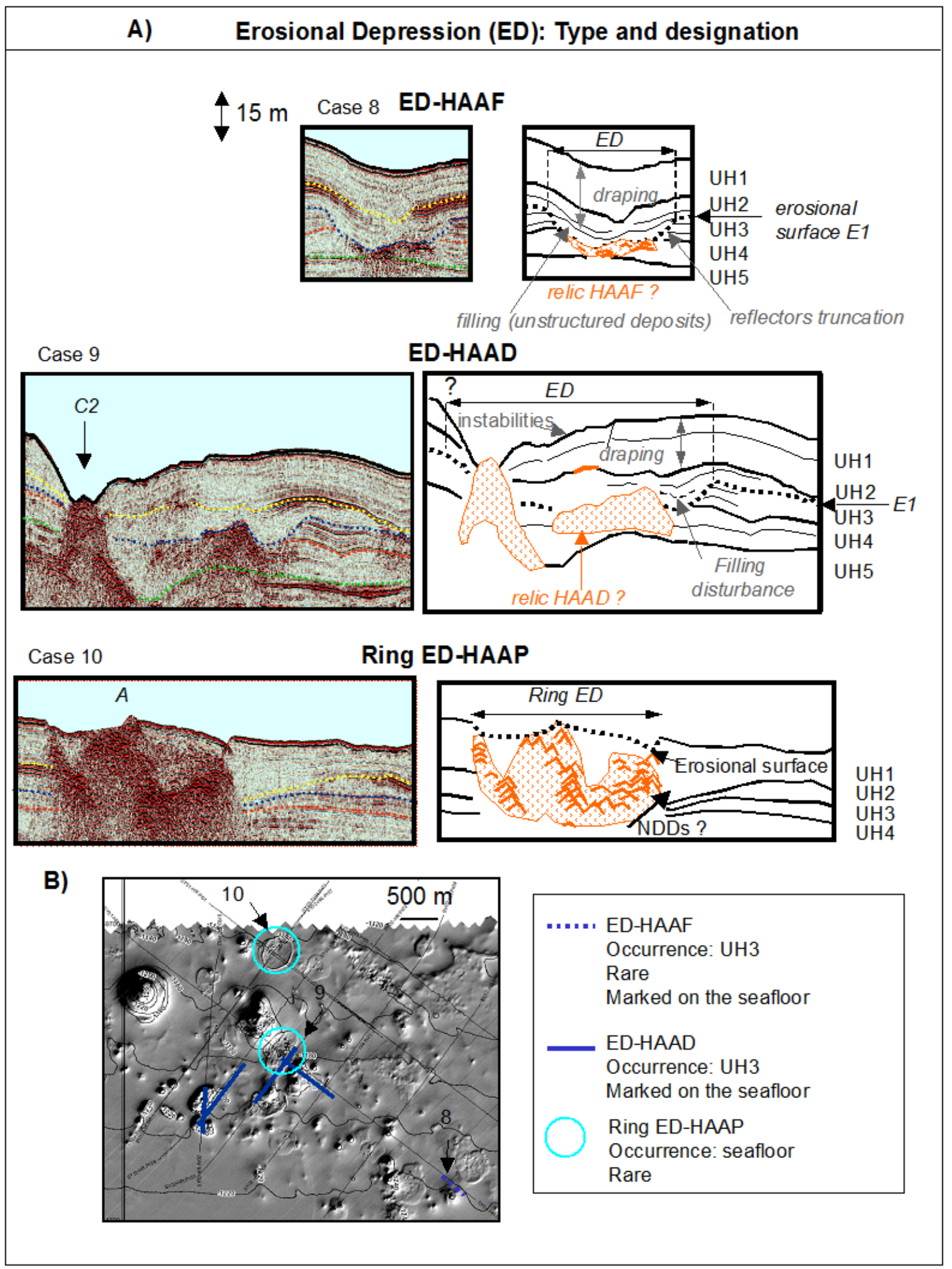









\section{Erosional Depression (ED): Type and designation}

\section{V-shaped ED}

A)

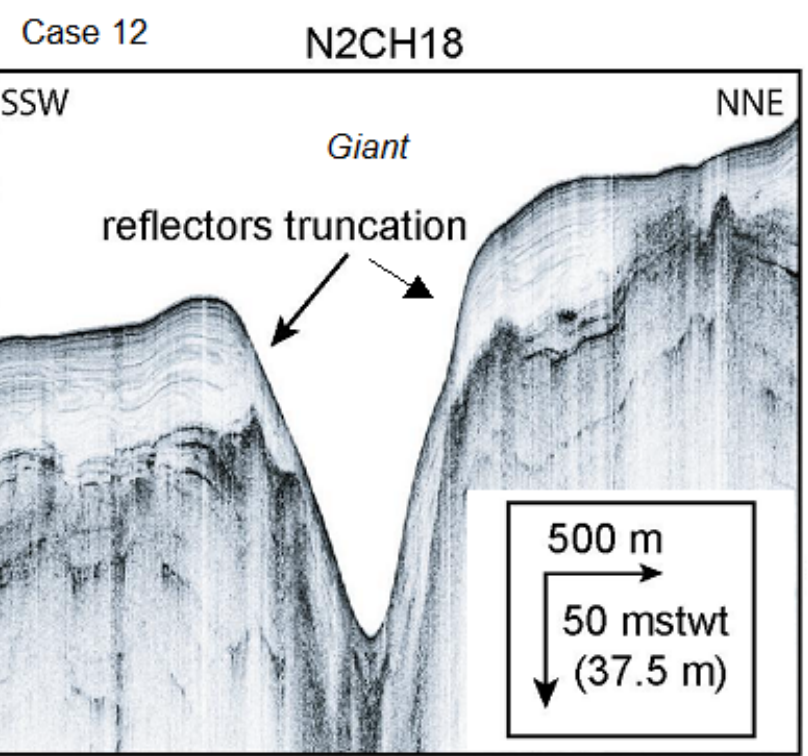

B)

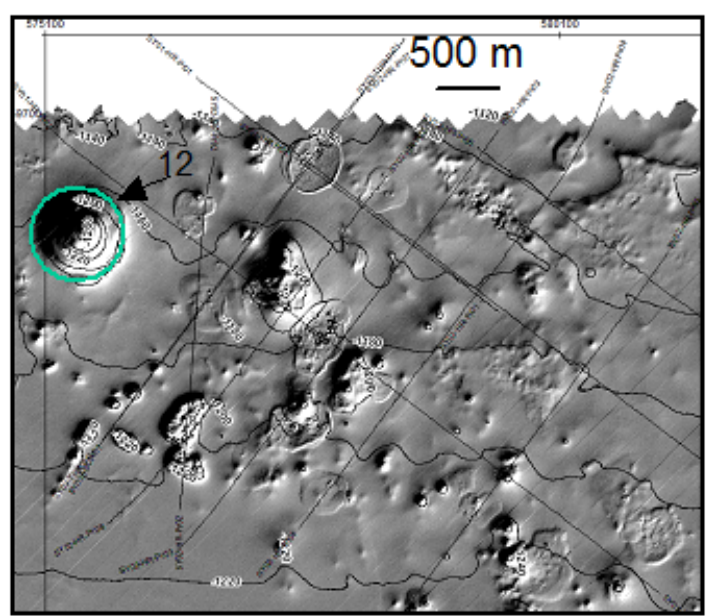




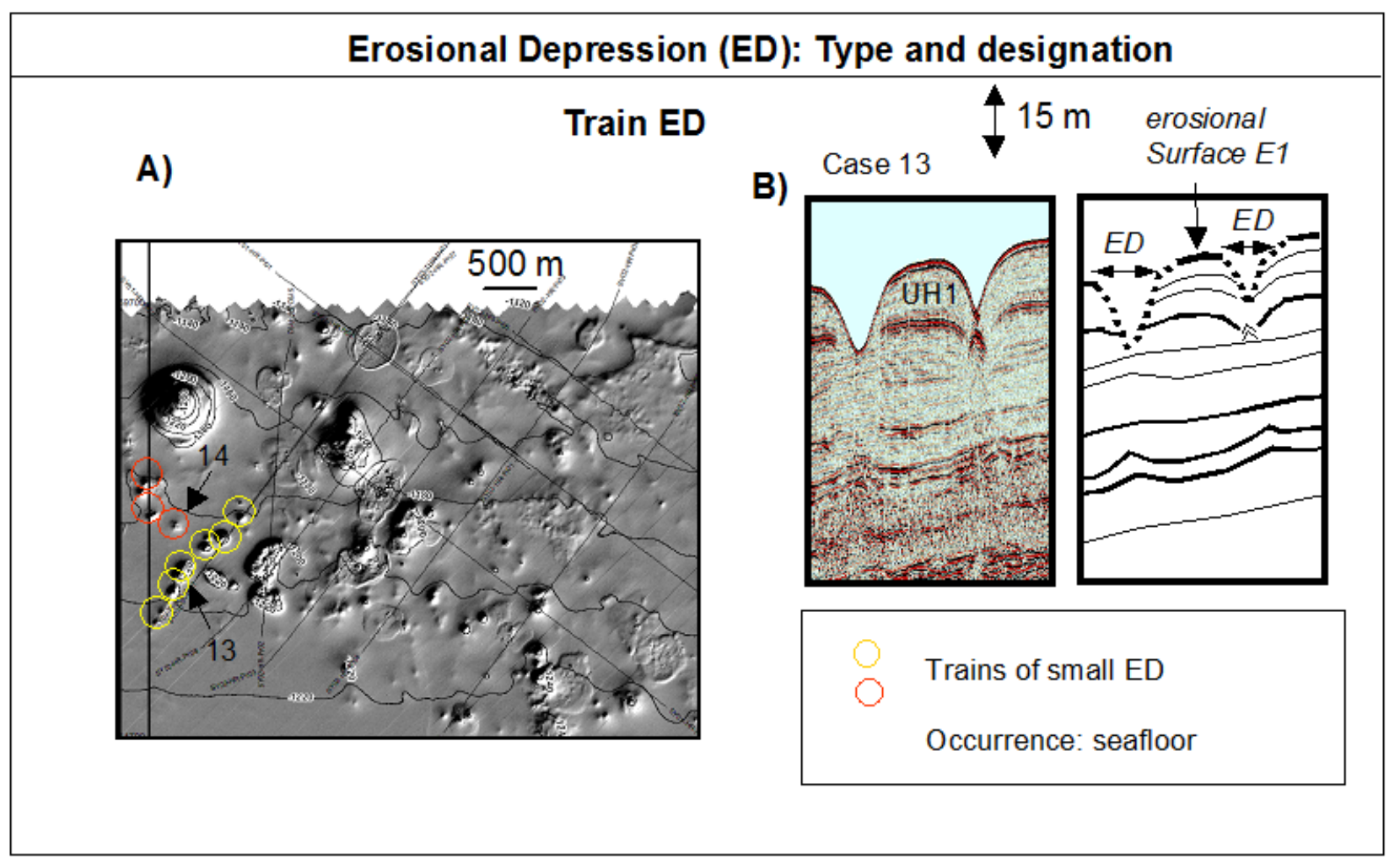


Topographic low related to paleo-depression

A)

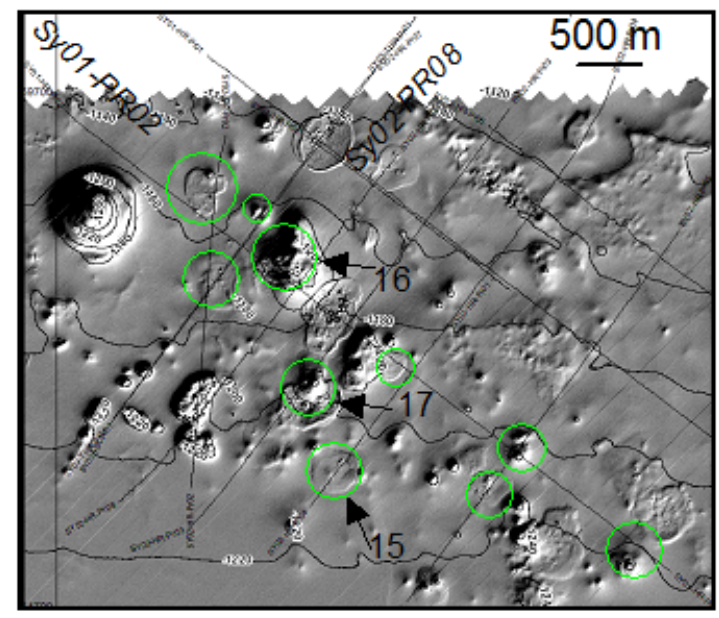

Occurrence: seafloor Frequent
B)

Topographic low over a buried NDD-HAAD

Case 15

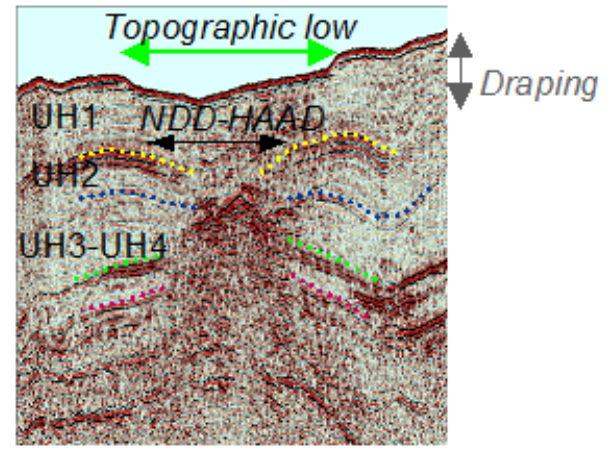

Sy01-PR02
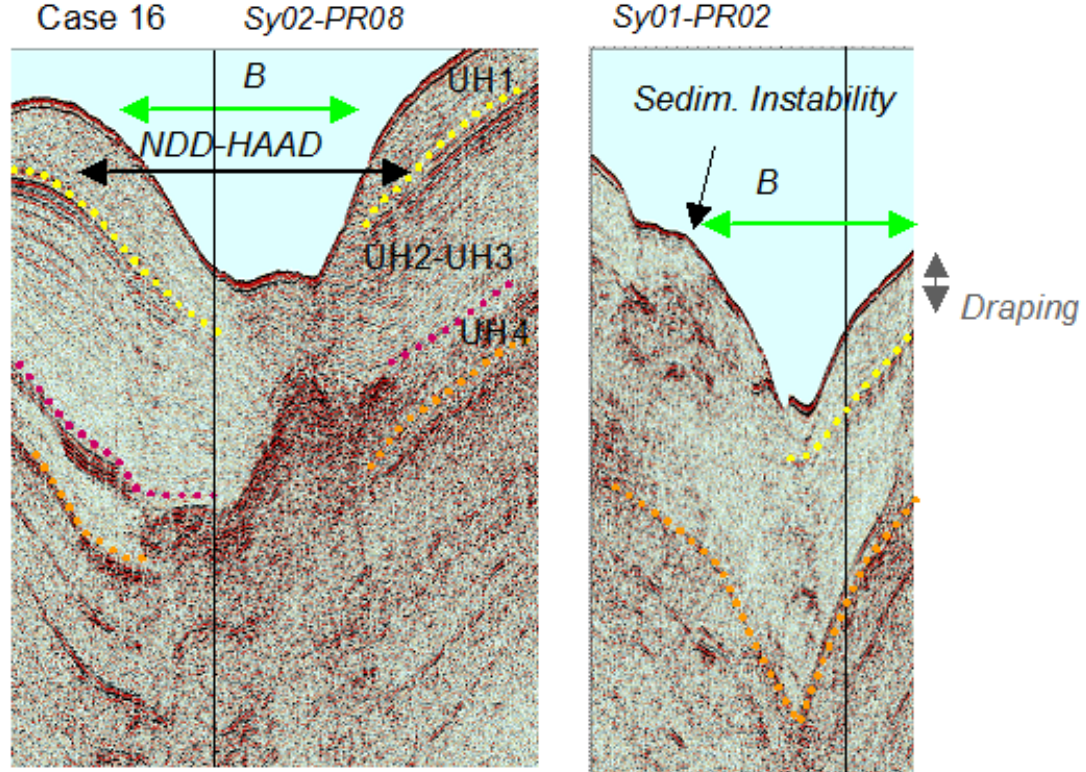


\section{Vertical Complex sequence}






\section{Buried features}

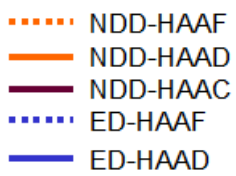

Seafloor features

Ring $\operatorname{ED}-\mathrm{HAAP}(+\mathrm{GH})$

CED-HAAD

V-shaped ED

Topographic low related to paleo-depression

NDD-haAC

Channel-Train ED

Fault-Train ED

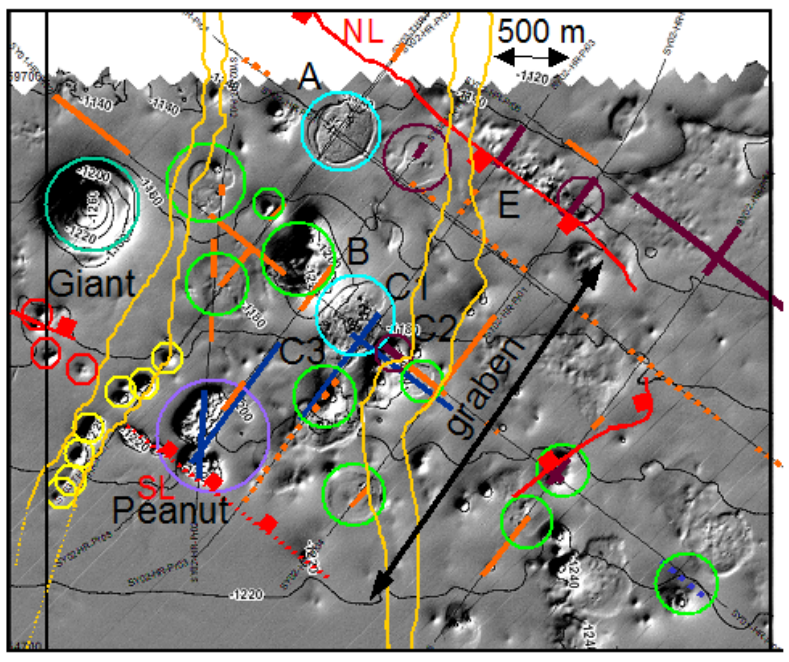






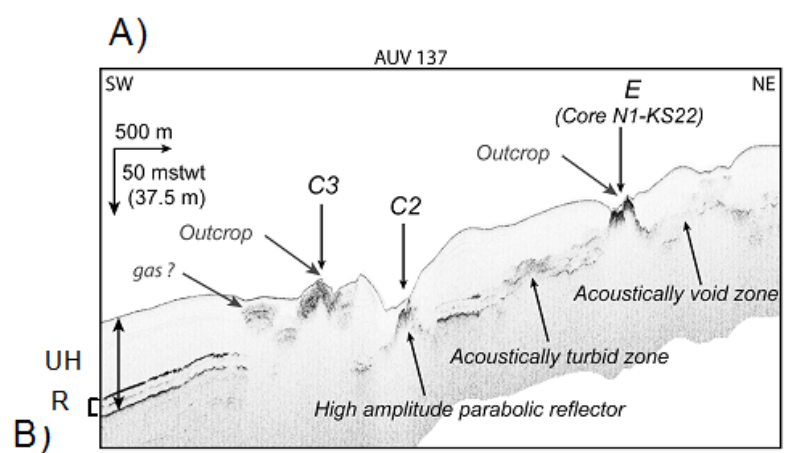

B)

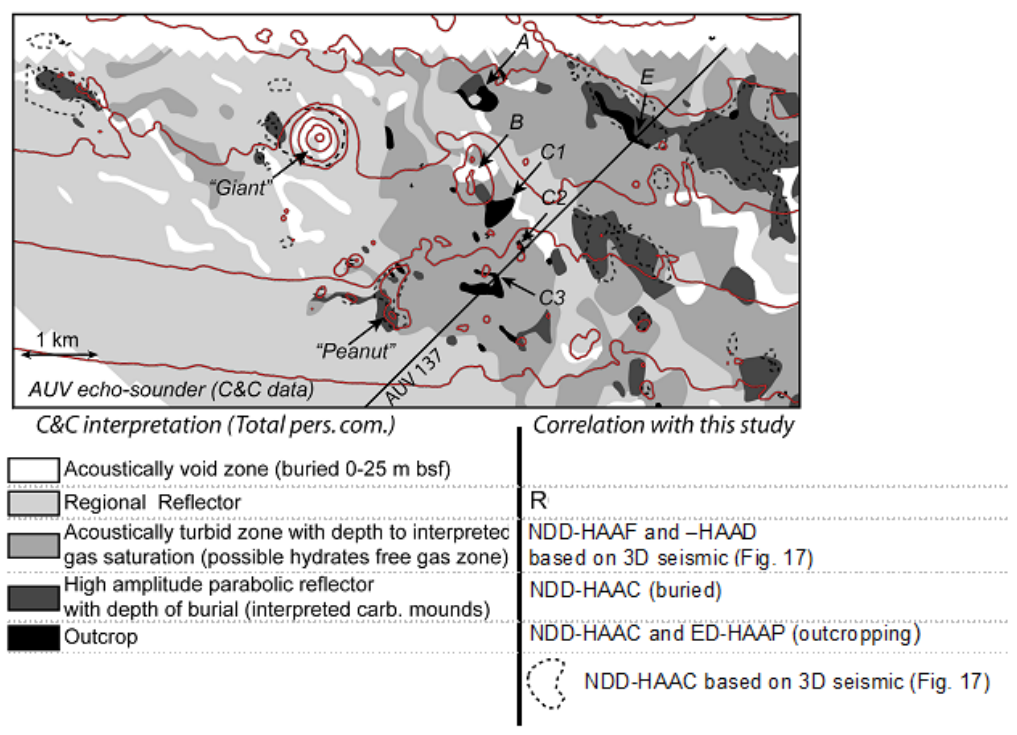


Proposition of an evolutionary sequence of fluid-related structures

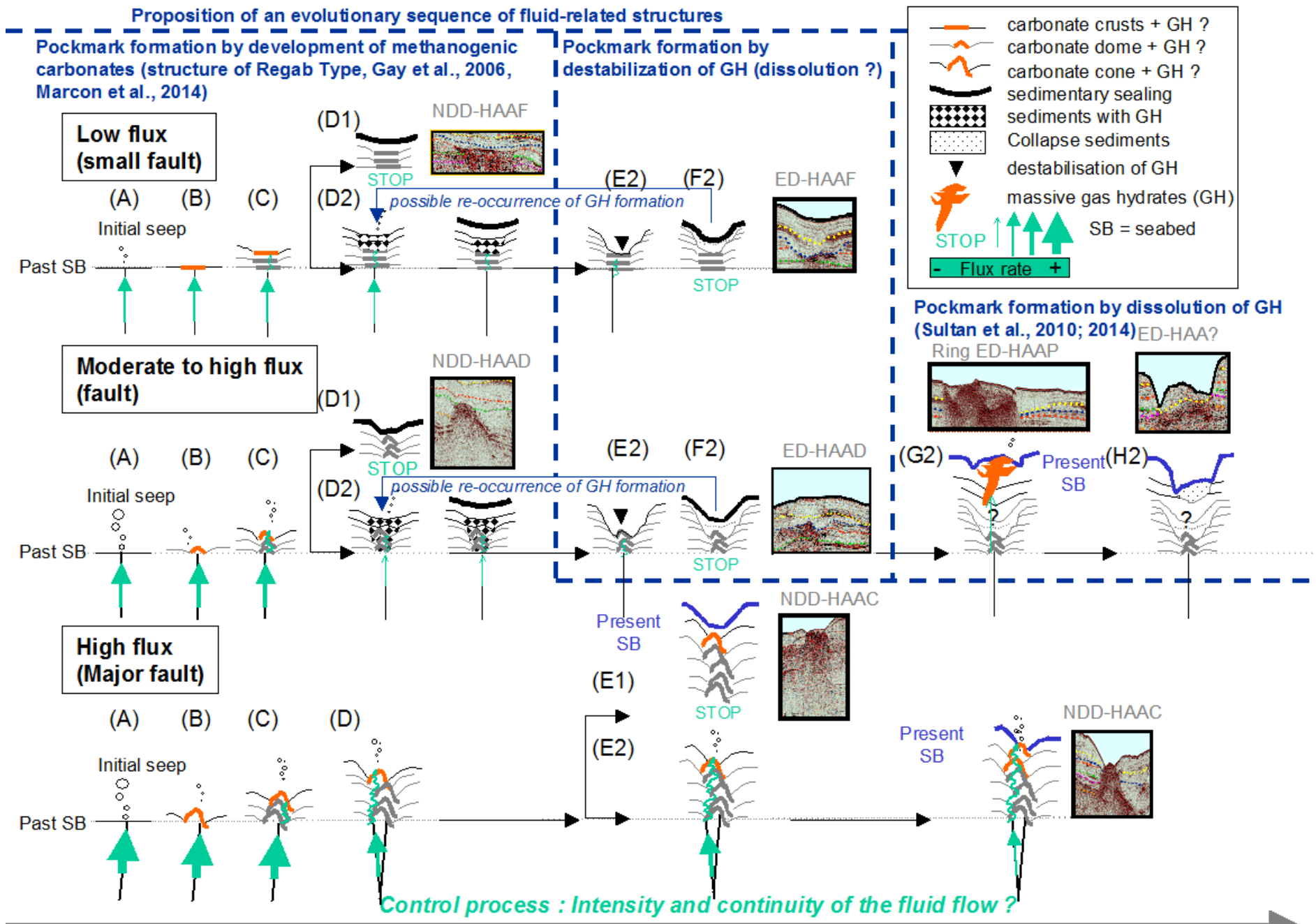


A)

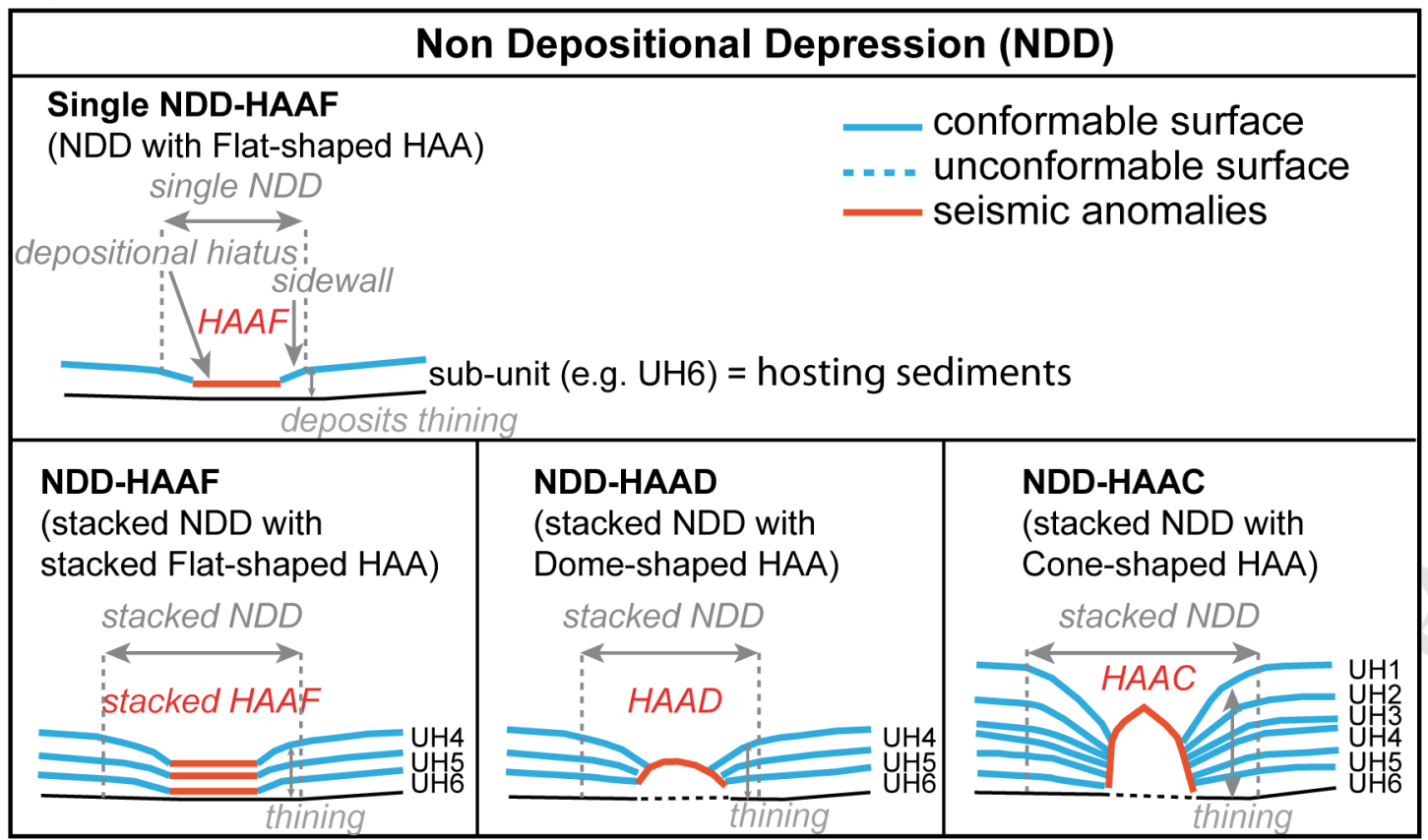

B)

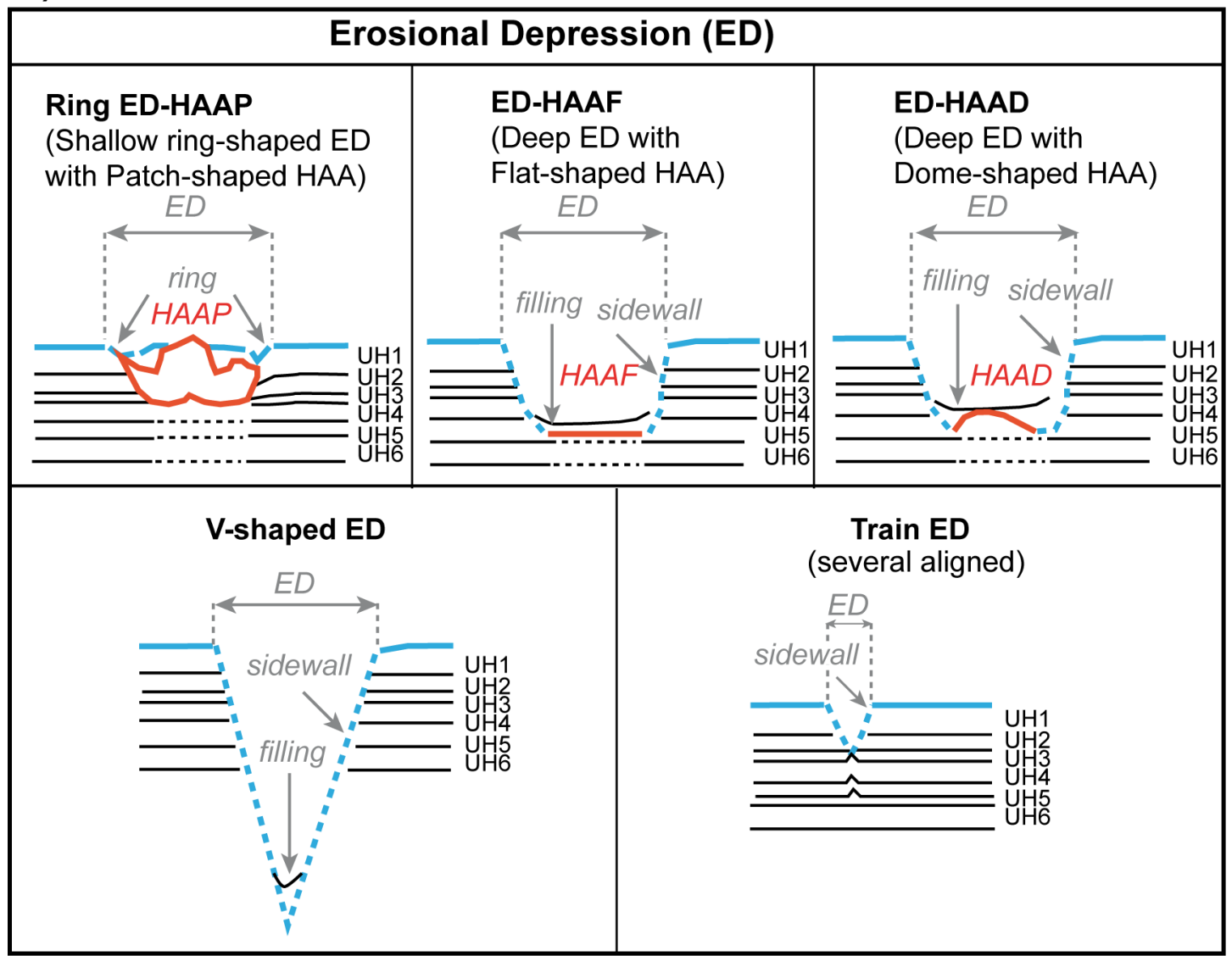


A)
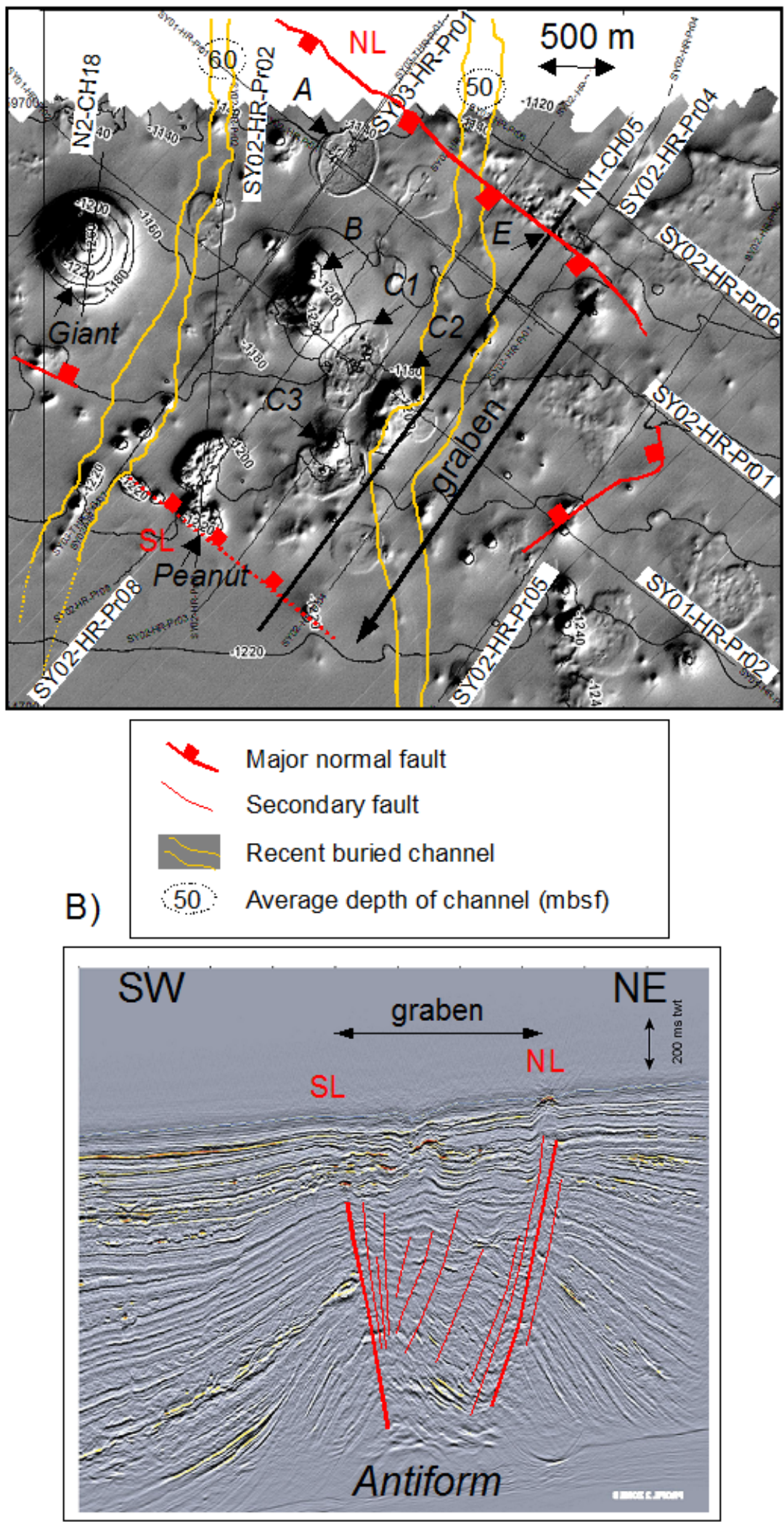
A)

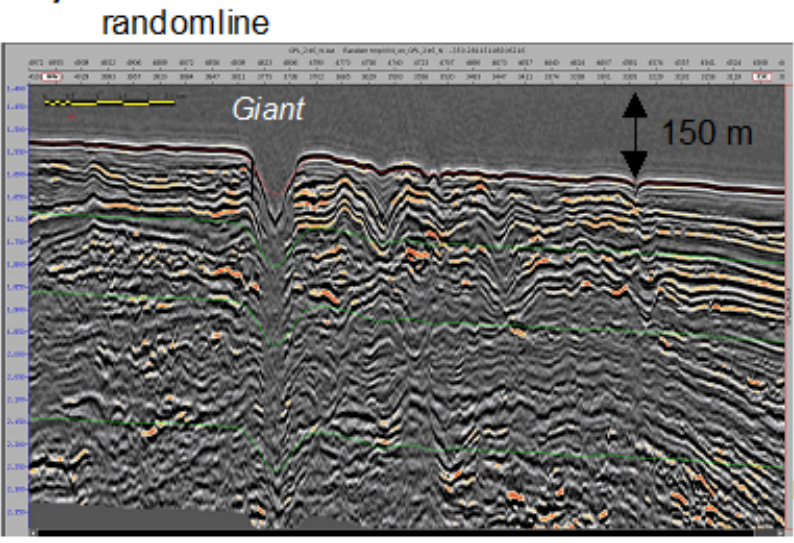

B)
C)

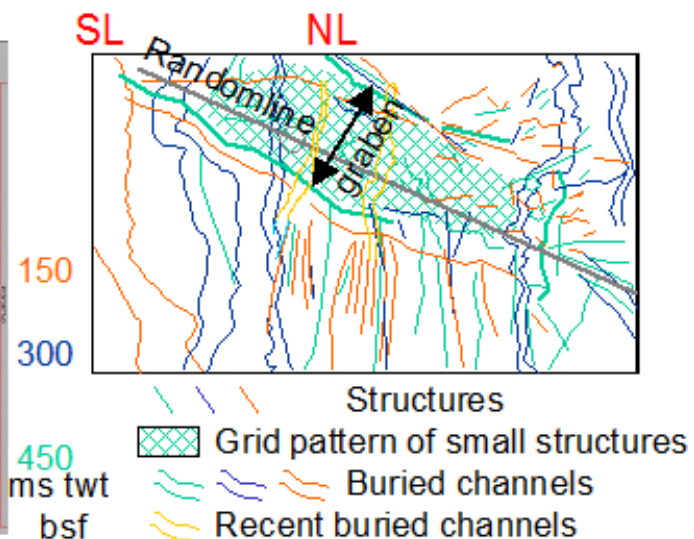

(see on Fig. 2)

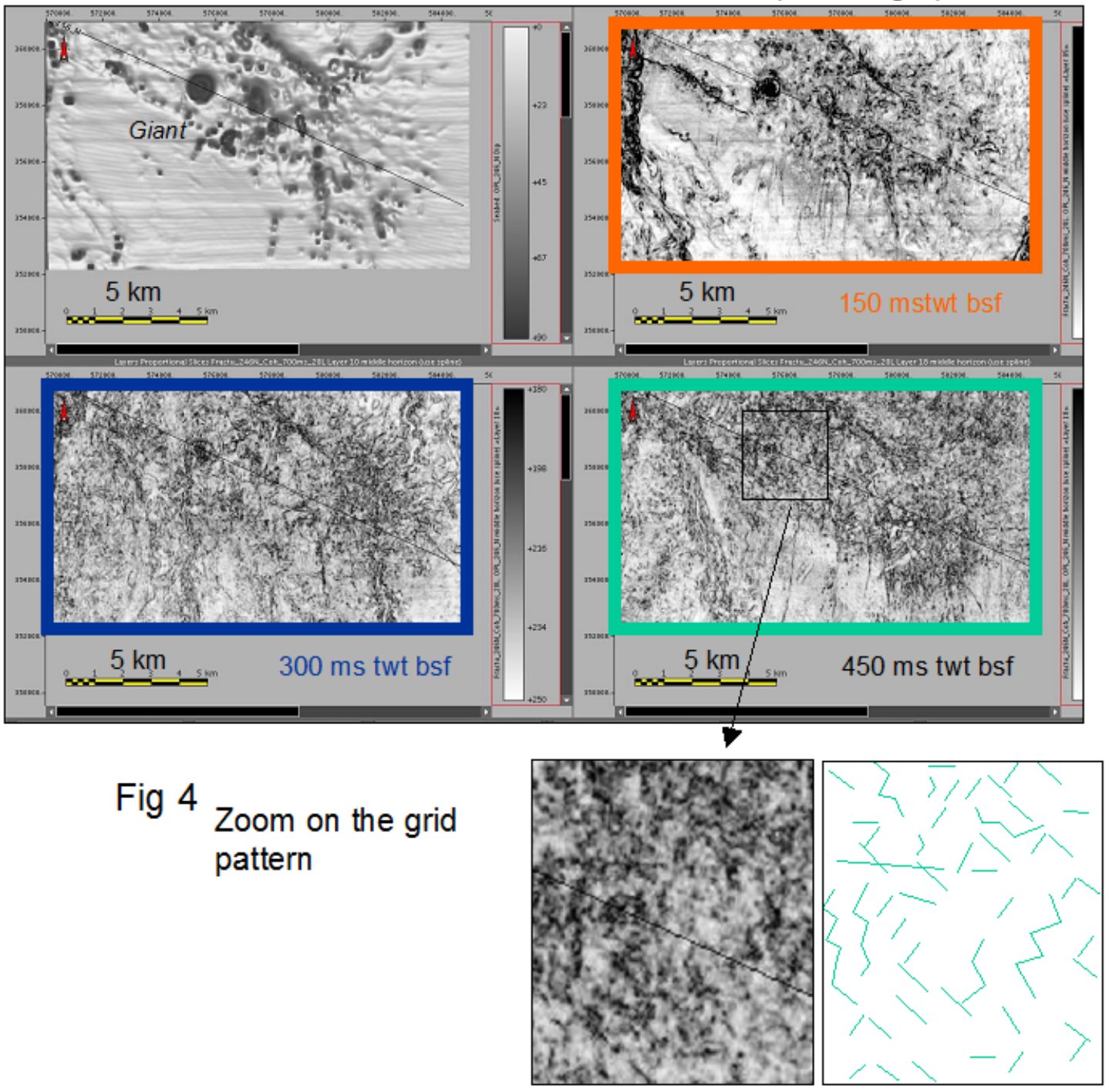


A) $\mathrm{NW}$ 3D line on Sys-01_Pr-02 profile


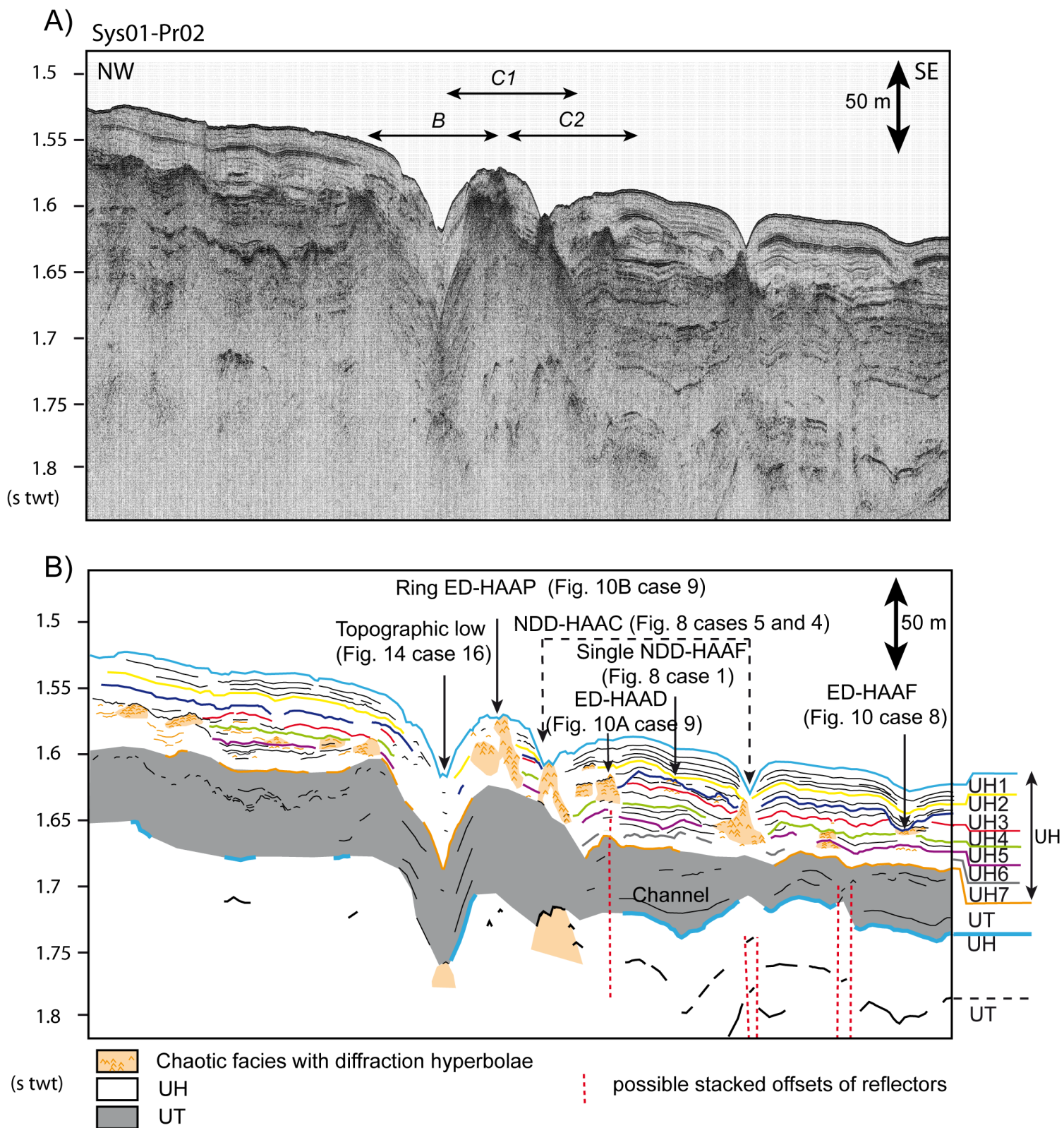




(ms twt)

possible stacked offsets of reflectors 


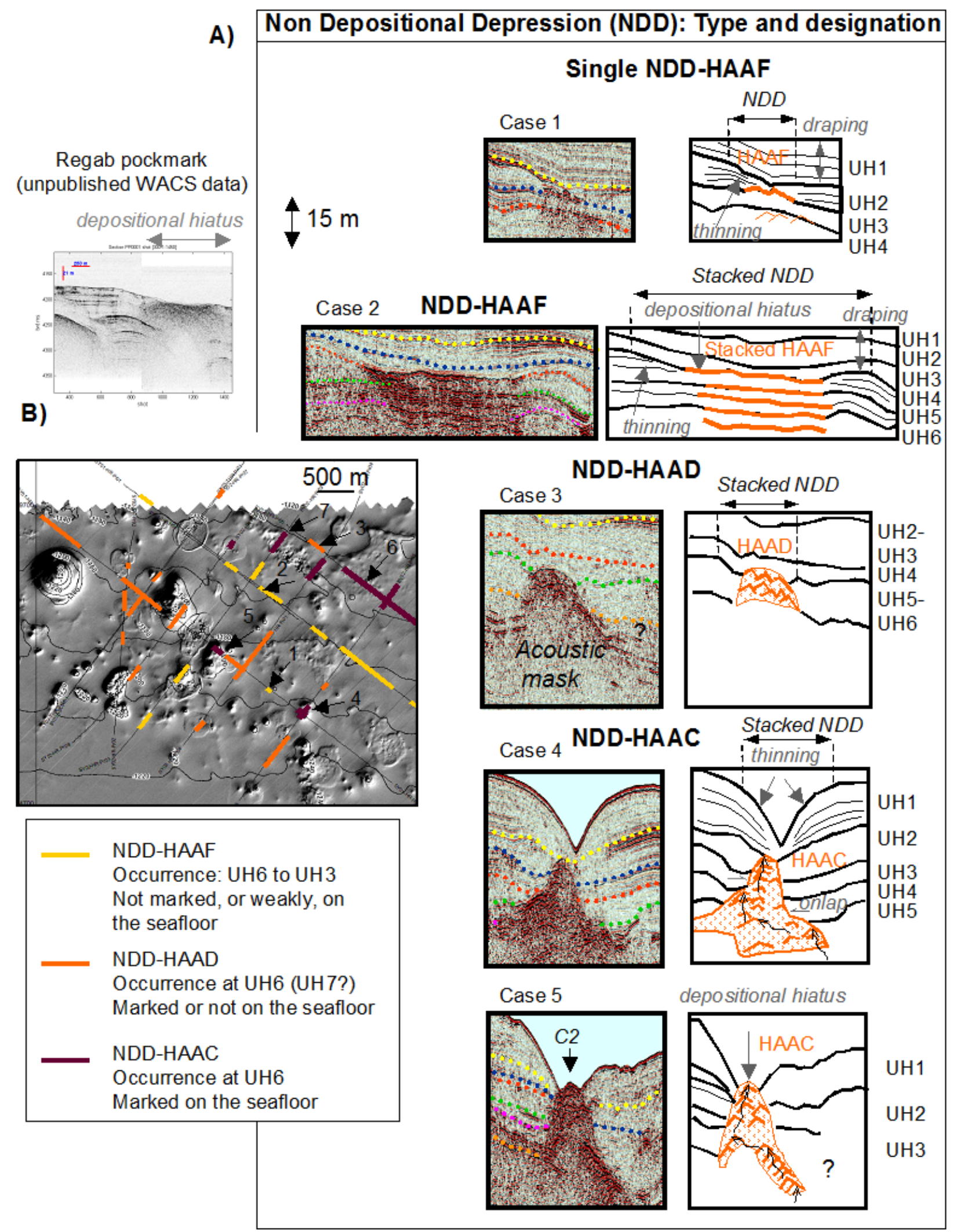




\section{NDD-HAAC in 'pavement'}
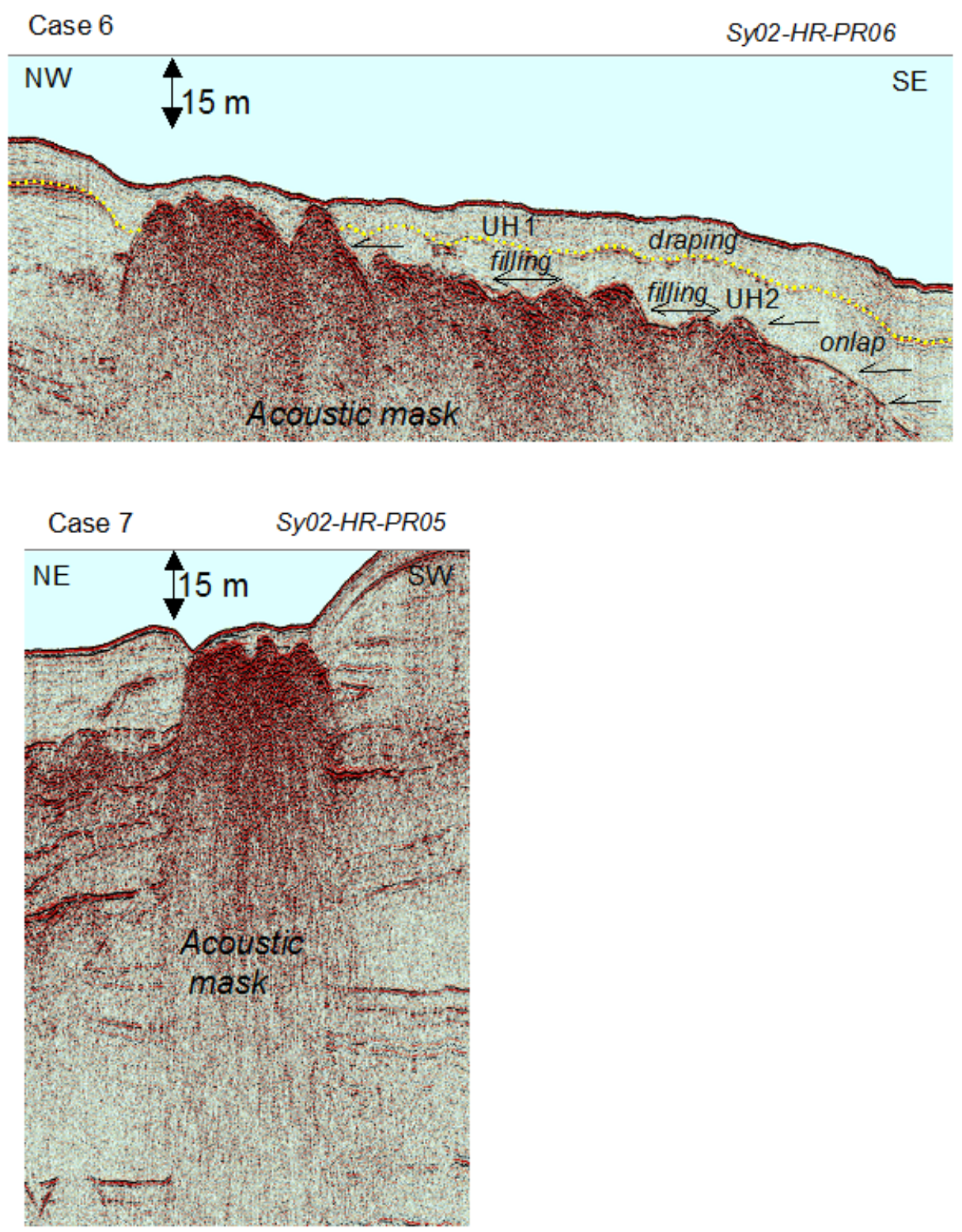